\title{
EXAMINATION OF SHAREHOLDERS STATUS WHO ARE UNABLE TO EXERCISE THEIR RIGHT OF PRIORITY IN CAPITAL INCREASE IN TERMS OF EQUITY AND CAPITAL ACCOUNTS ${ }^{1}$
}

\section{DOI: 10.17261/Pressacademia.2020.1209}

JEFA- V.7-ISS.2-2020(6)-p.134-154

\section{Suphi Aslanoglư ${ }^{1}$, Servet Ozkan², Suleyman Elci ${ }^{3}$}

${ }^{1}$ Kırıkkale University, Faculty of Economics and Administrative Sciences, Department of Business, Yahsihan, Kirirkkale, Turkey.

s aslanoglu@hotmail.com , ORCID:0000-0003-4394-5541

${ }^{2}$ Van Yüzüncü Yıl University, Van Vocational School, Tusba, Van, Turkey.

servetozkan@yyu.edu.tr, ORCID:0000-0001-8101-9173

${ }^{3}$ Kirıkkale University, Institute of Social Sciences, PhD Program in Accounting and Finance, Yahsihan, Kirikkale, Turkey. suleymanelci65@gmail.com,ORCID:0000-0002-0124-4950

Date Accepted: June 16, 2020

To cite this document

Aslanoglu, S., Ozkan, S., Elci, S., (2020). Examination of shareholders status who are unable to exercise their right of priority in capital increase in terms of equity and capital accounts. Journal of Economics, Finance and Accounting (JEFA), V.7(2), p.134-154.

Permanent link to this document: $\underline{h t t p: / / d o i . o r g / 10.17261 / P r e s s a c a d e m i a .2020 .1209 ~}$

Copyright: Published by PressAcademia and limited licensed re-use rights only.

\begin{abstract}
Purpose- The right of priority is an important problem in capital companies, especially in joint stock companies. The aim of the study is to reveal possible financial losses in equity items if minority shares are not able to exercise their primary rights in case of capital increase in joint stock companies.

Methodology - The study was conducted according to the qualitative research method, case study pattern. Sample Method was used to create the working group. In order to ensure the validity and reliability of data collection as a data collection tool in the research, document examination was applied in the direction of data diversification. In this context, data was collected by scanning articles and internet sources. $X$ A. operating in our country from the official website of Public Lighting platform within the scope of data set. The Balance Sheet, Income Statement and profit distribution table data were used and these data were tested and the results were tried to be obtained from the financial statements by means of benchmarking.

Finding- It is understood that minority shares in capital companies have probable financial losses in equity items if they are not able to exercise their priority right in raising capital at a cost. This condition is come up with the results of analysis and evaluation of the balance sheet, income statement and profit distribution table data of X A.Ş.

Conclusion- The findings of the study, with X A.Ş's balance sheet for the years between 31.12.2015 and 31.12.2016 and from income statement data for the same years were obtained. As a result of the transactions, there was a decrease in the shares of minority shareholders. In case of liquidation with previous year's profits, it was determined that there was a decrease in dividends and financial rights. Therefore, it was concluded that the rights of the former shareholders in the company should be determined in the market conditions, so that no partner, even if they are a minority, should be held in such a way as to avoid loss of rights, and that the regulations should not be based solely on the logic of majority vote.
\end{abstract}

Keywords: Equity, capital increase, priority right, capital reserves, profit reserves.

JEL Codes: G30, K30

\footnotetext{
${ }^{1}$ Çalışma ISPEC INSTITUTE tarafından 20-22 Aralık 2019 tarihleri arasında Van'da düzenlenen “ISPEC 3. ULUSLARARASI SOSYAL VE BEŞER BiLiMLER Kongresi'nde özet sunum olarak sunulmuştur.
} 


\section{SERMAYE ŞIRKETLERINDE BEDELLI SERMAYE ARTIRIMI YAPILMASINDA RÜÇHAN HAKKINI KULLANAMAYAN ORTAKLARIN ÖZKAYNAK HESAPLARI AÇISINDAN DURUMUNUN INCELENMESI}

\section{ÖZET}

Amaç- Rüçhan hakkı sermaye şirketlerinde özellikle anonim şirketlerde önemli bir sorundur. Çalışmada anonim şirketlerde bedelli sermaye artıımına gidilmesi halinde azınlık paylarının rüçhan hakkını kullanamamaları durumunda öz kaynak kalemlerinde muhtemel mali kayıpların ortaya çıkarılması amaçlamaktadır.

Metodoloji- Çalışma nitel araştırma yöntemi, örnek olay (case study) desenine göre yapılmıştır. Çalışma grubunun oluşturulmasında örneklem metodu kullanılmıştır. Araştırmada veri toplama aracı olarak ve geçerlikle güvenirliğinin sağlanması amacıyla veri çeşitlemesi yönüyle doküman incelemesine başvurulmuştur. Bu kapsamda makale ve internet kaynakları taranarak veriler toplanmıştır. Veri seti kapsamında Kamu Aydınlatma Platformu'nun resmi web sitesinden ülkemizde faaliyet göstermekte olan X A.Ş.'ye ait elde edilen Bilanço, Gelir Tablosu ve Kar Dağıtım Tablosu verileri kullanıımış ve bu veriler test edilerek kıyaslama yolu ile finansal tablolardan sonuca gidilmeye çalışılmıştır.

Bulgular- Sermaye şirketlerinde bedelli sermaye artırımında azınlık paylarının rüçhan hakkını kullanamamaları durumunda öz kaynak kalemlerinde muhtemel mali kayıplarının olduğu anlaşıımışır. Bu durum X A.Ş’ye ait Bilanço, Gelir Tablosu ve Kar Dağııım Tablosu verilerinin analiz ve değerlendirmeye tabi tutulması sonucunda da ortaya çıkmıştır.

Sonuç- Çalışmada elde edilen bulgular, X A.Ş’nin 31.12.2015 ile 31.12.2016 yıllarına ait bağımsız denetimden geçen bilançosu ile aynı yıllara ait gelir tablosu verilerinden faydalanılarak elde edilmiștir. İşlemler sonucunda azınlık durumundaki ortakların hisselerinde azalma olduğu ortaya çıkmıştır. Geçmiş yıl karları ile tasfiyeye gidilmesi halinde kar paylarında ve mali haklarda azalma olduğu tespit edilmiştir. Dolayısıyla bedelli hisse artıımında, eski ortakların şirket üzerinde olan hakları piyasa şartlarında tespitinin yapııması, böylece azınlık durumunda olsalar bile hiçbir ortağın hak kaybına uğramayacak şekilde düzenlemelerin yapılması ve düzenlemelerin sadece oy çokluğu mantığına dayandırılmaması gerektiği kanaatine varılmıştır.

Anahtar Kelimeler: Özkaynak, bedelli sermaye artırımı, rüçhan hakkı, sermaye yedekleri, kâr yedekleri. JEL Kodları: G30, K30

\section{GíRiş}

Sermaye şirketlerinde sermaye ön planda olduğundan sermaye tanımının yapılması konunun öneminin vurgulanması açısından yararlı olacaktır. Sermaye terimi iktisat, hukuk ve muhasebe bilimleri açısından farklı anlamlara gelmektedir. iktisat bilimine göre sermaye, katlanılan çabanın verimliliğini çoğaltan üretim araçları olup önceden üretilmiştir(Parasız, 2007: 512). Hukuk terminolojisi açısından bakıldığında ise sermaye, bir iktisadi işletme ya da ortak faaliyetin hedeflediği amacı elde etmek için işletme ya da ortaklığa bırakılan maddi veya maddi olmayan varlıkların parayla ifade edilebilen unsurların tümüdür(Inal, 2003: 854). Muhasebe bilimine göre, sermaye iki farklı kavram şeklinde ele alınır. Bunlar; "esas sermaye" ve "öz kaynak" şeklinde ifade edilebilir. Esas sermayenin tanımını yaparsak ticari bir faaliyete konulmuş olan para ve ya parasal olarak ifade edilebilen unsurların yekûnudur. Öz kaynak ise çok daha geniş bir anlamı ifade edilmektedir ve işletmenin kurucularının işletmeye yapmış oldukları yatırımların hepsini temsil eder(Collin, 2007: 84).

Sermaye şirketlerinin güçlü bir sermayeye sahip olması gerekmekte olup şirketler söz konusu sermaye ihtiyaçlarını iç finansman kaynaklarından karşılayabildikleri gibi dış finansman kaynaklarından da karşılamaktadırlar. Bu bağlamda sermaye şirketleri bedelli ve bedelsiz sermaye artırımlarına gitmek suretiyle ortaklarından veya üçüncü şahıslardan iç ve dış finansman yollarına başvururlar. İç finansman kaynakları yoluyla sermayenin artırılması yönteminin uygulamasında, yeni pay senetleri çıkarılarak mevcut şirket ortaklarına karşılıksız yani bedelsiz hisse olarak sermayeleri oranında verilebileceğinin yanı sıra, diğer bir şekilde elde bulunan halihazırda ki pay senetlerinin nominal bedellerinin arttırılması şeklinde de olabilir. Bu şekilde pay senetlerine ait nominal bedelin yükseltilmesi iç finansal kaynaklar ile sermaye artışı yoluna gidilmesi durumunda, hâlihazırdaki pay senetlerinin yazılı değeri, eklenen tutar nisabında artırılır ve yeni bedel, var olan pay senetlerinin üzerinde damgalanmak şeklinde gösterilir. Diğer bir ifadeyle, bedelsiz hisse senedi verilmesi suretiyle gerçekleşen sermaye artırımları, şirketlerin iç kaynaklarını oluşturan ve öz kaynakları arasında yer alan "sermaye yedekleri" ve "kâr yedeklerinden" yapılmaktadır. Sermaye yedekleri; hisse senedi ihraç primleri, iptal edilen ortaklık payları, yeniden değerleme veya maliyet artışı yapılması sonucu oluşan fonlardan meydana gelir. Kâr yedekleri ise; yasal, statü ve olağanüstü yedekler ile yedek niteliğindeki karşlıklar, özel fonlar vb. yanında işletmelerin ticari faaliyetlerinin sonucunda elde ettikleri karların şirket bünyesinde tutularak henüz dağıtımı yapılmamış parasal ifadelerdir(Çiftçi, 2000:1).

Bir başka finansman şekli olan bedelli sermaye artırımı ise, işletmelerin yeni finansman elde etmek için piyasaya sürdükleri "bedelli" hisselerini, nominal bedelle veya daha yüksek bir bedelden hâlihazır bulunan ortaklarına veya üçüncü kişi 
durumundaki yatırımcılara satmaları şeklinde gerçekleşmektedir(Borsa i̇stanbul, 2015). Bedelli hisse senedi çıkarılması yoluyla sermaye artırımına giden şirketlerin borsada işlem gören hisseleri ile ilgili tüm haberler ve firma ile ilgili bütün bilgiler kamuoyuna ilan edilir. Bu kamuoyuna ilan edilen haberlerden biri olan bedelli sermaye artırımı, işletmenin ileride daha yüksek getiriler elde etmek için yeni yatırımlara giriştiğinin ve daha güçlü bir finansal yapıyı amaçlaması bakımından piyasada olumlu bir haber olarak algılanır. Aynı zamanda bedelli sermaye artışı yoluna gidilmesi, halihazırdaki yatırımcılardan fon çıkışına sebep olacağından bu haberin olumsuz bir haber olarak görülmesi olasılığı da söz konusudur(Küçüksille \& Mizrahi, 2015:63-64).

Ticaret hukuku açısından konuya bakıldığında ise ilgili maddelerin şu şekilde olduğu görülmektedir; TTK 459'un 1.'nci bendinden anlaşıldı̆̆ına göre sermaye artırımına esas şirket payları hepsi ya değiştirilmiş ana sözleşmede ya da iştirak taahhütleri sözleşmesinde taahhüdü yapılır. 2'nci fıkraya göre iştirak taahhüt şekli yeni payların alınmasına ilişkin 461.madde kapsamında kayıtsız şartsız ve yazılı şekil şartına uyularak yapılmalıdır. İştirak taahhütnamesinde sermaye artırım taahhüdünün sebebi belirtilmelidir. Bunun yanı sıra hisselerin miktarını, kabul gören değeri, nev'ini, grubunu, ödenecek peşin bedeli, taahhüdün vadesini ve tedavül primi ile taahhüt verilenin imzası konulmalıdır. 3.fıkrasında böyle yapılacak sermaye artışlarında nakdi sermaye taahhütlerinde 341.madde, ayni(mal) sermayesinin konulmasında 342 ve 343 .maddeler, bedelin ödenmesinde 344 ve 345.maddeler, halka sunulanacak hisselerde 346.madde, ihraç edilecek hisselere 347.madde kıyaslanarak uygulanmaktadır.

TTK 461.madde 1.bendine göre ortaklıkta mevcut hisse sahipleri yeni çıkarılmış hisseleri var olan paylarını sermayeye oranlamasına göre alma hakkına sahiptir. 2.bendine göre şirket genel kurulunun sermaye artışı ile ilgili kararı pay sahiplerinin rüçhan(önalım) hakkı, haklı sebeplerin mevcut olması halinde ve sermayenin \% 60'ını temsil edenlerin olumlu oyları ile sınırlandırılabilir ya da kaldırılabilir. Rüçhan(Ön alım) hakkının sınırlandırılması ya da ortadan kaldırılması için kanundaki yaklaşım, hisselerin halka arz edilmesi, işletme bölümlerinin, iştirakin devir alınması ve çalışanların şirkete katılımı haklı ve doğru neden kabul edilir. Bu sebepler gerekçe gösterilerek oluşan önalım (rüçhan hakkı) hiçbir şekilde kısıtlanamaz, yok sayılamaz ve hiçbir tarafı haksız görecek şekilde faydalandırılamaz ve hak kaybına sebebiyet verilemez denilmektedir. Orana ait koşul hariç bu madde şartları kayıtlı sermaye sistemine tabi olunması durumunda yönetim kurulunun kararına da uygulanır. Şirket yönetim kurulu rüçhan(önalım) hakkının kısıtlanmasını veya yok sayılmasının nedenlerini, yeni hisselerin bedelli ve bedelsiz olarak çıkarıımasının dayanaklarını, bedelin nasıl belirleneceğini bir hesap raporuyla duyurur. Bu rapor tescil ve ilana tabidir.3.bende göre şirket yönetim kurulu yeni hisselerin alma şeklinin nasıl olacağını bir hüküm ile tanımlar. Bu haktan faydalanacaklara onbeş günlük bir zaman tanır. Ticaret Sicil Gazetesinde ilanı gerekir. Bunu yanında ilgili firmanın web sitesinde duyurur. Rüçhan(önalım) hakkı devredilebilir. Şirket ön alım hakkı tanınan hisse sahiplerinin bu haklarını kullanmaları kendi namına yazılmış hisselerinin devredilmesinin ana sözleşme ile sınırlandıııldığını ileri sürerek mani olamaz. Hukuki olarak da değinildiği gibi böyle bir yolla sermaye artırımında rüçhan hakkı kavramı ortaya çıkmaktadır. Bu hak bazen yerinde kullanılmakta bazen de ortakların hisse kayıplarıyla sonuçlanmaktadır.

Bu nedenle sermaye şirketlerinde ihtiyaç duyulan sermaye artırımlarının TTK'nın 462. maddesinde belirtildiği gibi sermaye unsurlarını oluşturan en önemli hesap gurubu olan öz kaynaklar, bilanço tarihindeki varlıklar toplamının ne kadarının işletme sahibi veya ortakları tarafından karşılandığını göstermektedir. Diğer bir ifade ile öz kaynaklar işletmenin hem kuruluş tarihinde hem de kuruluş tarihinden bilanço tarihine kadar işletmeye konan sermaye ile karların işletme bünyesinde bırakılması suretiyle sağlanan oto finansman kaynaklarını kapsamaktadır. Öz Kaynakları oluşturan hesaplar; Ödenmiş Sermaye, Sermaye Yedekleri, Kar Yedekleri, Geçmiş Yıllar Karları, Geçmiş Yıllar Zararları, Dönem Net Karı veya Zararı olarak gruplandırılmıştır. Bu çalışmada bu konu ele alınacak olup çalışma kapsamında azınlık hakları ve rüçhan hakkının kullanılamamasının sonucu olarak pay sahiplerinin öz kaynaklar hesap sınıfında maruz kaldıkları kayıpları ve bunun mali sonuçları üzerinde durulacaktır.

Çalışmada rüçhan hakkının ortaklar tarafından öncelikle kullanılmasının önemi üzerinde durulacağından, Türk Ticaret Kanunu'nun iç kaynaklardan finansmana ilişkin maddesine değinilecektir. TTK'nın ilgili maddesi gereğince; şirket bilançosunda sermayeye ilave edilmesine hukukun izin verdiği finansal kaynakların varlığı halinde, bu finansal kaynakların sermayeye ilave edilmeden, sermaye taahhüdü yoluyla sermaye artışına gidilemez. Bahsedilen fonlar hem sermayeye eklenerek hem de aynı nisapta sermayenin taahhüdü yoluyla sermaye artışına gidilebilir. Sermaye artış kararı şirket genel kurulun veya yönetim kurulunun bu yöndeki kararı ve esas sözleşmenin alakalı maddelerinde değişik şeklinde tescili ile kesinleşmiş olur. Tescil ile halihazırdaki hisse senedi sahiplerinin mevcut hisselerinin sermayeye oranınca bedelsiz hisseleri kendiliğinden elde ederler. Bedelsiz paylara ait haklar yok sayılamaz, kısıtlanamaz ve bu haktan feragat edilemez (TTK:462/3). Kanunda da belirtildiği üzere TTK iç fonlar varken dış finansmana gidilemeyeceği hükmünü getirmektedir. Bunun yanında iç kaynaklardan sermaye artırımı vergisel yönden de kazanç istisnası sağlamaktadır.

Öte yandan, dönem karından ayrılan yedeklerin sermayeye eklenilmesi suretiyle sermaye artırımına gidilmesi mevcut pay sahiplerine bedelsiz pay senedi verilmesi ile doğrudan kar payı verilmesi arasında herhangi bir farklılık yoktur. íki durumda da 
hissedarlar, işletme bünyesinde var olan karlar üzerinden tasarruf hakkına sahiptirler. Bu nedenle, kar yedeklerinden finanse edilen sermaye artışı sonucunda hissedarlarca bedelsiz iştirak payı elde etmeleri durumunda, elde edilen bu iştirak payları üzerlerinde yazılı bedelleri ile iştirak hesaplarında takip edilecek ve iştirak kazançları istisnasından dolayı kurumlar vergisi kesintisine yani stopaja tabi olmayacaktır. Bu durumda vergi istisnası yoluyla ayrıca kazanç elde edilecektir.

Çalışmamızda elde edilen veriler Kamu Aydınlatma Platformundan faydalanılarak X olarak nitelendirilen bir işletmenin gerçek verilerinden yola çıkılmış ve bu işletmenin verileri test ve analiz edilmiştir. Bu analizde $X A$ :Ş. verileri üzerinden mevcut karı ile kar dağıtımı yapılmıştır. X A.Ş'nin kar dağıtımı yapılmadan bedelli sermaye artırımına gidilmesi durumunda rüçhan hakkını kullanamayan ortakların durumu incelenmiş ve bu ortakların kar paylarında hak kaybına uğradıkları örneklem yoluyla tespit edilmeye çalışıımıştır. Bedelli hisse artıımının azınlık durumundaki hissedarlar açısından hem kar paylarında hemde sermaye paylarında bir azalmaya sebebiyet verdiği yapılan test ve analizlerle ortaya konmuştur. Ayrıca bedelli hisse artırımına gidilmesi ve bu hisselerin ortaklardan sadece bir kısmının faydalanması ya da dışardan ortak alınması durumunda bir taraftan mevcut şartlarda ortakların hak kaybına uğradıkları diğer taraftan tasfiye halinde kar payı ve sermaye haklarında kayıpların oluştuğu örneklendirilerek anlatılmıştır.

\section{AZINLIK KAVRAMI}

Azınlık esasında sermayenin yüzde onunu temsil eden pay sahipleri olarak tanımlanmaktadır. Bazen azınlık terimi tek tek bireyleri de ifade etmektedir. Bu nedenle rüçhan hakkının kullanılmasında en önemli unsur azınlık pay sahiplerinin haklarıdır. Türk Ticaret Kanunu'nun 411. maddesinde azınlık kavramı azlık olarak tanımlanmaktadır. Genellikle (1) şirket sermayesinin minimum \%10'nunu, halka açık işletmelerde \%5'ini temsil eden hisse sahipleri, şirket yönetim kurulundan, yazılı olarak zorunluluk sebeplerini ve gündemi belirleyerek, şirket genel kurulunu toplantıya çağırır veya şirket genel kurulu olağan toplantı yapacak ise, karar verilmesini istediği mevzuları toplantı gündemine alınmasını talep edebilir. Şirket ana (Esas) sözleşmesinde, genel kurulun toplantıya çağrılması hakkı azınlık pay sahipleri ortaklara da tanınabilir şeklinde azlık payı tanımlanmıştır (TTK:411).

Güçlüye göre; azınlık, mali işlemlerde kar dağıtımı veya bedelli hisse senedi ile sermaye artırımında temsil ettikleri hisselerin oranının büyük hisselerden az olanını temsil eden grup olarak tanımlanmaktadır. Bazen bir şirketin genel kurulunda sermayenin \%49'unu temsil eden hisseler azınlık olarak tarif edilirken, bazen de \%5'ini temsil eden hisseler çoğunluğu oluşturabilmektedir.

a)-Bir bakıma azık, şirket esas sermayesinin yarısından daha az kısmını elinde bulunduran ortaklardır ki; bu manada azınlık hisselerine TTK'n un tanımış olduğu bir hak ve yetki bulunmamaktadır.

b)-Şirket genel kurulunun herhangi bir oylamasında çoğunluğun içinde yer almayanlar manasındaki azınlık paylarının T.T.K.'nunca himaye durumu mevcut değildir. Sadece genel manada ki azınlık haklarının himayesine yönelik önlemlerden faydalanma hakları mevcuttur.

c)-Mevsuf Azınlık: Azlık terimi yukarıda belirtilenlerden ayrı olarak bir de yasa koyucunun belirlediği orana tekabül eden hisse sahiplerini ifade etmektedir ki; bu anlamda ki azınlık mevsuf (qualified minority) azınlık payları olarak tanımlanmaktadır. Çoğu zaman şirket için çok önemli kararlar alınması durumunda basit çoğunluk nisabı aranmasının yanı sıra azınlık hisselerine tanınmış olan hakların kullanılabilmesinde de genel manada azınlık kavramının içinde olan münferit hisse sahibi veya herhangi bir azınlık payı grubunun değil yasaların belirlediği bir nisabı meydana getiren hisse sahiplerine tanınmıştır. Azınlık haklarının faydalanılabilmesi için şirket esas sermayesinin TTK'nun ilgili düzenlemesine göre yüzde onuna, SPK düzenlemelerince de yüzde beşine sahip olunmasını gerektirmektedir(Güçlü, 2000:3-4).

Başka bir kaynakta SPK mevzuatına göre "halka açık anonim ortaklıklarda, şirket ödenmiş sermayesinin en az yirmide birini elinde bulunduran hisse sahiplerince kullanılabilmektedir" şeklinde tarif edilmektedir. Doktrinde azınlık hakları ikiye ayrılmaktadır. Bunlar; olumlu azınlık hakları ve olumsuz azınlık haklarıdır. Azınlık hakları bu iki başlık altında incelenmektedir. Olumsuz azınlık haklarına göre, şirket genel kurulunda yeterli sayı sağlanmış olsa bile, azınlık grubunun olumsuz oy kullanmak suretiyle karar alınmasını engellediği durumu ifade eder. Olumlu azınlık haklarına gelince, çoğunluğun iradesine ters olmasına rağmen, azınlık gurubunun irade açıklaması ile haklarını haklı bir talebe dayandırarak yada dava yoluna başvurmak suretiyle aramalarıdır(Canpolat., S.,S., 2008:161-163).

Yargıtay "Ortaklığın esas sermayesinin minimum onda biri tutarında hisseleri elinde bulundurmak azınlık haklarından faydalanmayı doğurur. Bu hak bir kişi de toplanacağı gibi birden çok paydaşın birlikte hareket etmesi halinde de oluşur." şeklindeki kararıyla bu görüşü benimsemiştir(Manop, 2008:11). 
Yukarıda anlatıldığı üzere, azınlık haklarına hukuksal olarak çok önem verilmekte fakat yasal olarak bazı paradokslar nedeniyle kanuni yollara başvurulmasında ve tüketilmesinde azınlık haklarının kullanılması biraz zorlaştırımıştır. Azınılık paylarının çok olması ve hisseleri ellerinde tutan paydaşlarının birbirinden uzaklığı ve hak düşürücü süreler nedeniyle azınlık hakları bazen korunamamaktadır.

\section{LITERATÜR ÖZETI}

Parasız’a (2007) göre sermaye, katlanılan çabanın verimliliğini çoğaltan üretim araçlarıdır. İnal'a (2003) göre ise bir iktisadi işletme ya da ortak faaliyetin hedeflediği amacı elde etmek için işletmeye bırakılan maddi veya maddi olmayan varlıkların parayla ifade edilebilen unsurların tümüdür. Collin (2007) işletmenin kurucularının işletmeye yapmış oldukları yatırımların hepsini temsil eder şeklinde tanımlamıştır. Türk Ticaret Kanunu (459-461) Sermayenin artırılabileceği ve bu artışın nasıl yapılabileceği açıklanmıştır. Sermaye artırımına giden işletmelerde iki türlü artırım söz konusu olmaktadır. Bedelsiz hisse çıkarılması ya da bedelli hisse çıkarılması yoluyla gerçekleşmektedir. Bedelsiz hisse çıkarılması ancak var olan hisse bedellerinin artırılması ya da yeni hisse çıkarılarak ortakların sermayesi oranında ortaklara bedelsiz olarak dağıtılması şeklinde gerçekleşmektedir. Bedelsiz hisse çıkarılması iç kaynakların sermayeye aktarılması ile mümkündür. Çiftçi'ye (2000) göre bedelsiz hisse çıkarılması sermaye yedekleri ve kar yedeklerinden yapılmaktadır. Bedelli hisse çıkarılması durumunda ise işletme dışından işletmeye yeni ortak alınması ve hisselerin bedelli olarak piyasaya sunulması şeklinde gerçekleşmektedir.

Küçüksille \& Mizrahi (2015)'ye göre bedelli hisse çıkarılması işletmede daha güçlü bir finansal yapının oluşması açısından piyasada olumlu bir haber olabileceği gibi, mevcut yatırımcılardan fon çıkışına sebebiyet verdiğinden olumsuz bir haber olabileceği olasıı̆ı̆ının da göz ardı edilmemesi gerektiğini ifade etmektedir. Bedelli hisse çıkarılması durumunda mevcut ortaklar için rüçhan hakkı doğmaktadır. TTK 461. maddesi mevcut ortakların sermaye oranında rüçhan hakkını kullanabileceği vurgulanmış ancak sermayenin \% 60'nı temsil edenlerin olumlu oyları ile sınırlandırılabileceği ya da ortadan kaldırılabileceğini hüküm altına almıştır. Ayrıca bedelli hisselerin mevcut ortaklar tarafından alınabilmesi, yani rüçhan hakkının kullanılabilmesi 15 günlük bir süreye bağlanması, süre bakımından da kısıtlılık getirmektedir. Er, Şahin, vd.'ne (2015) göre, işletme dışı kaynaklar işletme içi kaynaklara göre çok daha fazla çeşitlidir. Bunlardan bazıları borçlanma yoluyla da elde edilebilmektedir. Gençoğlu, Önce vd'ne (2013) göre ise işletme içi kaynakların sermayeye aktarılması yoluyla sermaye artırımına gidilmesi halinde, artırım karşıı̆ığı tedavül edilen pay senetlerini mevcut ortaklara sermaye payları oranında bedel karşıı̆ı̆ olmaksızın dağıtılması gerektiği ifade edilmiştir. Eriş (2009) aynı konuya değinerek sermaye artırımının iç kaynaklardan yapılması halinde bedelsiz hisselerin ortaklara dağıtılması ve buna karşlık bir bedel istenmemesi gerektiğini belirtmiştir.

Kanunda belirtilen \%60'ık oran çoğunluk ve azınlık kavramlarını da ortaya çıkarmaktadır. TTK' 411. maddesinde azınlık haklarından söz edilmiş ve sermayenin \%10'nunu temsil edenleri azınlık olarak nitelemiştir. Bu oran halka açık işletmelerde \%5 olarak ifade edilmiştir. Güçlü 'ye(2000) göre azınlık kavramını mali işlemlerde kar dağıtımı veya bedelli hisse senedi ile sermaye artıımında temsil ettikleri hisselerin oranının büyük hisselerden az olanını temsil eden grup olarak tanımlamıştır. Bu durumda sermaye payının yarısından az olan tutarda hisseyi elinde bulunduran ortaklar azınlık olarak nitelenebilmektedir. Canpolat (2008) azınık hakkının kullanılmasında olumlu azınlık hakkı ve olumsuz azınlık hakkı şeklinde ele almaktadır. Azınlık durumundaki ortakların hukuki olarak başvurabilecekleri yolları tanımlamakta ve bu yolların kullanılmasını olumlu veya olumsuz hakkın kullanımı şeklinde yorumlamaktadır. Manop (2008) bir Yargıtay kararına dayanarak, ortaklığın esas sermayesinin minimum onda biri tutarında hisseleri elinde bulundurmak azınlık haklarından faydalanmayı doğurur. Bu hakkın bir kişide veya birden çok kişinin aynı konuda birlikte hareket etmesi şeklinde kullanılabileceğini ifade etmektedir.

Özsungur, (2014) sermaye artırımına gidilmesi durumunda dikkat edilmesi gereken önemli hususun işletmedeki menfaat dengesinin korunması olduğu ve yapılan işlemin gerçeği yansıtması gerektiğini ifade etmiştir. Ayrıca, sermaye artırımının rüçhan hakkını kısıtlanmasını gerektiren bir durum sözkonusu olduğunda işletmenin çıkarları kapsamında bir işlem yapılmasının doğru bir karar olduğunu da vurgulamıştır.

Cosetti \& Meo (2012) İtalya Ticaret Hukuku'na göre, sermaye artırımında dış kaynak kullanılması durumunda, mevcut hissedarların menfaatlerinin korunması için hisse satış fiyatlarının gerçek piyasa değeriyle değerlenmesine özen gösterilmesi gerektiğini vurgularken, eski hissedarların katlandıkları maliyetlerin doğru hesaplanması gerektiğini belirtir. Elde edilen kazanımların mevcut hissedarların çabaları sonucu ortaya çıktığını belirtirken, çıkarılacak hisselerin primli olması eski ve yeni hissedarlar arasındaki pozisyonun dengelenmesi için gerekli olduğunu ifade etmektedir.

Cenkçi (2016) Alman Yüksek Mahkemesinin kararına dayanarak çoğunluk hisselerinin gücünün sınırsız görülerek ve kötü niyetli olarak şirket zararına kullanılmaması ve sübjektif iyi niyet olarak kullanılmasının görmezden gelinmesinin ahlaka aykırı olduğu yönünde karar aldığını ifade ederken, bu hakkın kötü niyetli olarak azınlığı kayba uğratacak şekilde kullanılmaması gerektiğini vurgulamaktadır. 
Watson, McKenzie vd.'ne (2019) göre İngiliz ve Galler Ticaret Hukuku'nda azınlık haklarının korunmasında sermaye paylarını esas almış ve oy oranlaması ile azınlığın yapabileceklerini maddeler halinde sunmuştur. Azınlık hissedarları, şirketi kontrol eden yöneticilerin davranışlarına karşı yardım talep eden ve haksız önyargı iddiasında bulunabileceğini ve hissedarların mağduriyeti sebebiyle şirketin adil bir şekilde elden çıkarılmasını isteyebileceklerini vurgulamışlardır. Ayrıca şirketin işleri, pay sahiplerinin tamamına ya da bir kısmına zarar verecek şekilde yürütülürse bu azınlık pay sahiplerinin mahkemelere başvurma hakkının doğurmaktadır. Hisse senetlerinin sınırlandırılması ancak ya hissedarlar anlaşması ya da azınlık pay sahiplerine verilen veto hakkıyla olabileceğini açıklamıştır.

Timmerman L. ve Doorman,A (2019) Hollanda Şirketler Hukuku'na dayanarak, azınlık hisselerinin zayıf olması nedeniyle bu konunun önem taşıdığını, azınlık haklarının iyi korunması gerektiğini vurgulamışlardır. Azınlık hakkının korunmasını ayrıca ülke ekonomisinin güçlenmesi yönünden ele almış ve yabancı yatırımcının ülkede yatırım yapması amacıyla, ister küçük ister büyük hisse sahibi olsun tüm hisse pay sahiplerinin korunmasını kamu düzeni kapsamında değerlendirmiştir. Aynı zamanda genel kurul kararlarının azınlık hakkını ihlali durumunda azınlığın yasal yollarla hakkını korumayı gerektiğinde bu hakkın bir vakıf veya dernek aracılığıyla korunabilmesine imkan vermiştir.

Çetinyılmaz (2017) İsviçre şirketler hukukunda azınlık haklarının korunmasında, şirket hisse sahipleri herhangi bir kısıtlamaya tabi tutulmaksızın rüçhan hakkını kullanabileceğini vurgulamıştır. İsviçre Federal Mahkemesi verdiği bir kararda işletmenin sermaye artışına gitmesi durumunda, hissedarlara tanınan rüçhan hakkı eşit işlem ilkesi dikkate alınarak kullanılmalıdır hükmünü vermiştir.

\section{RÜÇHAN HAKKI}

Sermaye şirketlerine has rüçhan (önalım) hakkı, esas sermayenin dış kaynak kullanılarak sermaye artışı sonucunda meydana gelen hisseleri öncelikli olarak almayı sağlayan hakkı ifade eder. Rüçhan hakkı esasen malvarlığı ile ilgili bir haktır. Bu nedenle rüçhan hakkı sermaye şirketlerinde kullanılan bir hak olması nedeniyle; bir kere bu hak (özellikle) dış kaynaklı sermaye artırımlarında karşımıza çıkar. Çünkü şirketin serbest yedeklerinden yapılan "iç kaynaklı" sermaye artırımlarında, pay sahipleri bu yeni payları bedelsiz alma hakkına sahiptir(gratis-bedelsiz paylar)(Bozkurt, T.,2014:219). Ayrıca hukuk sistemimizde Rüçhan Hakkı olarak bilinen yararlanma hakkını, TTK'nun 461. Maddesi (1) Mevcut hisse sahipleri, yeni çıkarılan şirket paylarını, sahip oldukları paylarının sermaye nisabınca ön alım hakkına sahiptirler denmek suretiyle bir anlamda tanımlanmıştır.

Yani; TTK Mad. 461'e göre sermaye şirketlerindeki her pay sahibi, çıkarılan yeni payları mevcut paylarının sermayeye bölünmesi sonucu ortaya çıkan oran kadar itibari değer nispetinde alma hakkına sahiptir. Özellikle sermaye şirketlerinin içinde çok önemli yeri olan Anonim şirketlerde rüçhan hakkı, pay sahibine yeni pay alma hakkı tanıyan ancak bu alım hakkının çıkarılan yeni paylar ile mevcut paylar arasındaki orantı nispetinde olan, sübjektif, paya bağımlı ve nispi haktır. (2) 6102 sayılı TTK m. 461 vd. hükümlerinde, bedelli sermaye artırımına gidildiğinde, çıkarılan yeni payların alınmasında pay sahibinin öncelik hakkının vurgulanması amacı ile "rüçhan hakkı" kelimesinin kullanıldığı madde gerekçesinde ifade edilmiştir. Anılan hüküm, pay sahipliğinde öncelik haklarını düzenleyen "Bezugsrecht" başlığı altındaki OR Art. 652b'den etkilenmiştir(Özsungur, 2014:147). 6102 sayılı TTK'nunda rüçhan hakkını sınırlandırmak veya kaldırmak haklı sebeplerin varlığı halinde mümkün olmaktadır.

Rüçhan hakkının sınırlandırılması ve ortadan kaldırıması azınlık haklarının ihlali anlamına gelir. Aslında bu hakkın korunması azınlık haklarının sulandırılmasını engelleyecek, küçük pay sahiplerinin güvencesini arttıracaktır. TTK'nun 461/2.bendi uyarınca "Önalım (Rüçhan) hakkı sınırlandırılmak ve kaldırılmak suretiyle, hissedarlardan hiçbiri haklı çıkarılmak ve faydalandırılmak suretiyle hak kaybına uğratılmamalıdır. Karar yeter sayısına ait usul şartının dışında bu karar kayıtı sermaye sitemine tabi şirket yönetim kurulunu alacağı kararlarda da geçerlidir. Şirket yönetim kurulu önalım (Rüçhan) hakkını sınırlandırılma ve kaldırma sebeplerini ve tedavül edecek hisse senetlerinin primli ve primsiz çıkarılma sebebini, prim hesaplama esaslarını bir rapor ile duyurur, hesap raporu tescil ve ilana tabidir. İfade edildiği gibi ayrıca, Sermaye Piyasası kanunun 18/5 maddesi gereğince; “(5) Şirket yönetim kurulunun; imtiyazlı yada üzerinde yazılı bedelden fazla veya az hisse senedi çıkarılması, mevcut pay sahiplerinin yeni hisseleri almalarının sınırlandıııması veya imtiyaz tanınan hisse sahiplerinin haklarını sınırlandıracak yönde karar alabilmesi şirket ana sözleşmesinde yetkili kılınmasına bağlıdır. Yeni hisse alma hakkının sınırlandırılması şirket hissedarları arasında eşitsizliğe yol açacak şekilde olamaz. 6102 sayılı TTK' nın 461'inci maddesinin 2'inci ve 3'üncü fıkralarının hükümleri halka açık ortaklıklar için uygulanmamaktadır" şeklinde ifade edilmiştir.

Kanun metninden de anlaşıldığı üzere, rüçhan hakkını akamete uğratacak rastgele kullanılacak bir yasal yol olmadığı gibi bunun objektif olarak iyi niyet esasları çerçevesinde kullanılması gerekmektedir. 
Rüçhan hakkının finansal olarak da ele alınıp üzerinde durulması gerekmektedir. Rüçhan (yeni pay alma) hakkı: Hisse senedi sahipleri sermaye artırımı amacıyla şirketin ihraç edeceği yeni tertip hisse senetlerinden sermaye payları oranında yeni hisse senedi alma hakkına sahiptir. Bu hak genel kurulda kısıtlanabilir. Eğer bu hak olmamış ve yeni ihraç edilmiş hisse senetleri yeni yatırımcılara satılmış olsaydı eski hissedarların hem oy hem de temettü hakları sulandırılmış olurdu.

Mali açıdan; rüçhan hakkının doğması için ihraç edilecek yeni hisselerin, satış fiyatıyla şirketin hisse senetlerinin pazar değeri arasında, artı bir değerin olması gerekir. Aksi halde ortaklar için rüçhan kazancı doğmaz. Şirket genel kurulda alacağı bir kararla rüçhan hakkını sınırlandırabilir. İhraç edilecek hisse senetlerinin mesela yarısının rüçhan haklı, kalanının ise normal satılmasına karar verebilir.

Buradan hareketle; Rüçhan hakkı aşağıdaki formülle hesaplanabilir.

$\mathrm{Ro}=\mathrm{Po}-\mathrm{Ps} / \mathrm{N}+1$

Burada Ro rüçhan hakkının teorik değerini, Po pay senedi piyasa (Pazar)fiyatını, Ps Pay senedi ortaklarına satış fiyatını, N yeni pay senedi almak için gerekli eski hisse sayısını göstermektedir(Okka, 2015: 861).

Yukarıda bahsedildiği gibi rüçhan hakkı, ortada bir haklı sebep yokken kullanılabilecek hukuksal bir hak olmayıp paydaşların pay oranlarının korunması kardan pay alması, genel kurulda oy kullanması mali ve idari hakların korunmasını sağlayan bir müessese olarak görülmektedir. Ortaklar tarafından kullanılması durumunda mali olarak kazanımlar sağlarken kullanılmaması durumunda mali kayıplar meydana getirmektedir.

\section{SERMAYE ŞIRKETi PAYDAŞLIĞINDA YÜKÜMLÜLÜK VE HAKLAR (ÖZKAYNAKLAR)}

Işletmenin kişilik kavramı gereğince işletmenin kendisi "birinci kişiliği”, işletmenin sahibi durumundaki ortaklar "ikinci kişiliği”, borç verenlerde "üçüncü kişiliği" ifade eder. İşletme sahipleri yani ikinci kişiler aracılığı ile elde ettiği finansmana öz kaynak, borç verenler yani üçüncü kişiler aracılığı ile elde edilen finansal kaynaklara ise yabancı kaynaklar denmektedir. İster işletmenin sahipleri ister üçüncü şahıslar olsun işletmeye sağladıkları kaynakların sonucu olarak işletme üzerinde hakları söz konusu olmaktadır. Bu hak varlıklar üzerindeki hak olarak bilinmektedir. Bir başka anlatımla öz kaynaklar grubu işletme sahiplerinin işletme varlıklarına ait tasarruflarını muhasebe dilinde ifade ederken, yabancı kaynaklar gurubu üçüncü kişiliği temsil eden işletmeye dış finansman sağlayanların işletmenin varlıklarına ait haklarını ifade etmektedir.

Anonim Şirket paydaşlığında işletmenin bir tüzel kişiliği olup, bu da hissedarlara bir takım mali yükümlülükler ve alacak hakları sağlamaktadır. Sahiplik anlamında sistematiğin esasında işletmenin kişilik kavramı bulunur. Bu kavram gereği bir işletmenin iktisadi kişiliğinin, yani işletmeye ait varlıklar ve bu varlıklardan dolayı ileri sürülebilen haklardır. İşletmenin mevcudiyeti ve mevcudiyetin devamı ile faaliyetlerini sürdürebilmesi gerekir. İşletme ticari faaliyetlerinde devamlılığı sağlayabilmesi için başta likid varlıklar (nakit para) olmak üzere bir takım varlıklara gereksinim duyar. İşletmenin iktisadi kişiliği bu varlıkları tamamen karşılamada aciz kalabilmektedir. Bundan dolayıdır ki işletmelerin ekonomik kişiliklerinin ihtiyaç duyduğu varlıklar ya işletme sahiplerinden veya üçüncü kişilerde (ticari kredi) sağlar. İşletmeye bırakılan iktisadi varlılar işletmenin varlığını oluştururken, hukuki anlamda bir tüzel kişilik, ekonomik anlamda ise ekonomik kişiliğe sahip olarak bir varlık sahibi olacaktır. Dolayısıyla, işletme iki tür kaynağa sahiptir bunlardan biri öz kaynak, diğeri ise yabancı kaynaktır.

Buna göre kaynak baz alındığında işletmeler için finansman, bir işletmenin devam eden ve yapılacak yatırımları için gereken fonun yani nakit veya sermayenin bulunmasıdır. İhtiyaçları olan fon kaynaklarını oto finansman yoluyla yani işletme içi finansal kaynaklardan sağlayabildiği gibi işletme dışı finansal kaynaklarda başvurabilmesi imkan dahilindedir. İşletmelerin öz kaynakları olarak da ifade edilen iç kaynaklar, işletme sahibi durumundaki ortaklarının mal varlığı ile faaliyet kârından oluşmaktadır. Genel olarak bütün işletmeler kurulum evrelerinde, dış finansman kaynaklarına ulaşma konusunda zorluk yaşamalarından, kendi öz sermayelerini kullanmaya meyillidirler. İç kaynaklardan finansman dış kaynaklara göre daha az maliyetlidir. Ancak iç kaynaklar yeterli olmadığından büyüme ve ilerleme aşamalarında genellikle dış finansal kaynağa ihtiyaçları olur. İhtiyaç duydukları bu fonları karşılayabilmek için banka kredilerine, finansal kiralamaya (leasing), faktoringe, girişim sermayelerine, yurtiçinde ve yurtdışında bulunan finansman kurumları ile sermaye piyasalarındaki çeşitli kredilere başvurmak suretiyle dış finansal kaynaktan istifade ederler. İşletme dışı kaynaklar işletme içi finansal kaynaklara kıyasla çok çeşitlilik ve farklılık göstermektedir. Bahsedilen finansal kaynakları işletmelerin bir bölümü borçlanma yolu ile bulurken bazıları sermaye artırımı yolunu tercih etmektedirler(Er, Şahin vd, 2015:32).

Bu nedenle, işletme bünyesinde bulunan kaynaklarda her paydaşın hisse oranında hakkı bulunmasından yola çıkarak yapılacak sermaye artırımı iç kaynaklardan yapıldığında her bir ortağın işletme üzerindeki hakkı mahfuz kalmak üzere işlemlerin 
yapılması gerekmektedir. İşletmelerde bedelsiz sermaye artırımında iki temel kalemden yararlanır. Bunlar; iç finansal kaynaklar yoluyla sermayenin artırılması ve karın pay senedi olarak dağıtımı.

İşletmeler, genellikle yeni bir fon oluşturmak için, yeni hissedarlar alma yâda pay senedi tedavül etmek suretiyle sermayenin artırılması yolunu seçmektedir. Bu yolla dışardan gelecek sermaye artışı yeni bir kaynak oluştururken, işletmenin yeni ortak veya ortakları da oluşmaktadır. Şayet iç kaynaklardan yani "sermaye yedekleri" ve "kar yedekleri" veya geçmiş yıllarda elde ettiği ancak dağıtılmamış karları sermayeye aktarmak şekliyle sermaye artırımına gidildiğinde yeni ortak veya ortaklar olmadığı gibi mevcut ortaklar tarafından sermaye artırımı yapılmış olacaktır. Oto finansman yoluyla sermaye artırımı olarak da bilinen iç kaynaklardan fon sağlama ya sermaye yedekleri kullanılarak ya da kar yedekleri veya her ikisi de kullanılarak yapılır. Sermaye yedekleri sınıfı; hisse senedi ihraç primlerini, hisse senedi iptal karlarını, yeniden değerleme yapılması sonucu meydana gelen fonları oluşturmaktadır. Kar yedekleri sınıfı ise; yasal, statü ve olağanüstü yedekler ile yedek benzeri karşılıkları ve özel fonların takip edildiği hesaplardır. Bu hesaplarda biriken meblağların sermayeleştirilmesi yolu ile sermayesini artıran sermaye (anonim) şirketi, artırım karşılı̆̆ı tedavül edilen pay senetlerini halihazırdaki ortaklarına sermaye payları nisabında "bedel karşıı̆ı̆ı olmaksızın" dağıtır. Bu sermaye artırımı sonucu şirket ortaklarına verilen paylara "bedelsiz hisse senetleri" denilmektedir(Gençoğlu, Önce vd., 2013:11-12).

Diğer bir ifade ile işletmeler, bilançolarında birikmiş geçmiş yıllar kârları, yeniden değerlemeden doğan fonları ve daha önce biriken yasal yedek olarak ayrılan fonları sermayeye ilave edebilmektedir. Buna oto finansman ya da iç kaynaklardan sermaye artıımı denilmektedir(Eriş, 2009:35). Tekdüzen hesap planı ve muhasebe sisteminin tanımlamış olduğu öz kaynak hesapları adından da anlaşıldığı gibi paydaşlara hisseleri oranında sorumluluklar yüklemekte ve aynı zamanda kazanımlar da sağlamaktadır.

\section{AZINLIK PAYLARININ RÜÇHAN HAKKINI KULLANAMAMALARI SONUCUNDA ÖZKAYNAK HESAPLARINDAKI KAYIPLARI}

İşletme ve ortaklar açısından, öz kaynaklar, şirket ortaklarının işletmenin sahip olduğu varlıklara ilişkin haklarının tanımıdır. Öz kaynaklar, genel olarak işletmenin safi varlıkları ile ticari yükümlülükleri (borç) arasındaki pozitif fark olarak bilinir. Ticari işletmede öz kaynak kalemleri, ödenmiş sermayeyi, sermaye yedeklerini, kar yedeklerini, geçmiş yıl karlarını veya zararlarını, faaliyet dönemi karını veya zararını ifade eder(Gençoğlu vd., 2013:141). Anonim şirket azınlık pay sahipleri bazı sebeplerden dolayı kendilerine tanınan rüçhan hakkını ilandan sonra gerek mali yetersizlikler gerekse süreyi kaçırmak suretiyle kullanamamaktadırlar. Ayrıca Türk Ticaret Kanunu'nun 461. maddesinin 2. bendinde, genel kurulun mevcut sermayeyi artırma kararı ile hisse sahiplerinin önalım (rüçhan) hakkı, sadece hâkli bir sebebin olması halinde asgari esas sermayenin yüzde altmışının lehte oy kullanılması ile sınırlandırılabilir veya ortadan kaldırılabilir, şeklindeki yaklaşımı rüçhan hakkının kullanılamaması intimalini doğurmaktadır. Önalım (Rüçhan) hakkının nasıl sınırlandırılacağı tamamen kaldırıımasına dair meşru nedenler yasa yapııı tarafından örnekli ve istisnaları sayılarak anlatılmıştır. Bu örnekleyici ve istisnai durum için, hisselerin halka sunumu, bir işletmenin veya işletme bölümlerinin, iştirakin devri ve çalışanların şirkete katılmaları gibi sebepler haklı sebep kabul olunmaktadır. Haklı sebepler için çeşitli yaklaşımlar söz konusu olduğundan bu örnekleri daha da artırılabilir. Bunlara ilave olarak böyle bir durum hâsıl olduğunda dikkat edilmesi gereken önemli husus işletmedeki menfaat dengesinin korunmasıdır. Diğer dikkat edilmesi gereken husus ise yapılan işlemin gerçeği yansıtması ve önemli bir gerekçeye dayanmasıdır. Esasen rüçhan hakkının kullanılmasında sınırlama sözkonusu olduğunda şirket çıkarları kapsamında bir işlem yapılması doğru bir karar olur(Özsungur, 2014:148).

Yukarıda da belirtildiği üzere öz kaynak hesapları ortaklara bazı kazanımlar sağladığı gibi rüçhan hakkının kullanılmaması veya kullanılamaması halinde hisse oranında bir mali hak kaybına sebep olmaktadır. Sermaye ve kar yedekleri ile geçmiş yıllar karları ortakların sermaye yani öz kaynaklar üzerindeki kayıplarını temsil etmektedir.

\section{ULUSAL VE ULUSLARARASI HUKUK AÇISINDAN RÜÇHAN HAKKININ KULLANILMASININ KARŞILATIRILMASI}

Rüçhan hakkının kullanılması ülkemizde ve diğer ülkelerde farklı süreçlerden oluşmaktadır. Ülkemizde rüçhan hakkı kullanımı, dış kaynaklardan faydalanılarak sermaye finansmanında gündeme gelmekte olup TTK'ya göre genel kurulun yüzde altmış çoğunluk sağlaması durumunda dış finansmana gidilmekte, yüzde onluk azınlık payları da rüçhan hakkını kullanma yoluna gidebilmektedir.

İtalyan Ticaret Hukukunda; Anonim şirket sermaye artırımlarında; şirket, çıkarılan yeni hisselerin satış fiyatını belirlerken hisselerin nominal değerlerinin üzerine bir miktar daha ekler. Satış fiyatı ile nominal değer arasındaki fark hisse senedinin primi/kar payı olarak bilinir. Şirketin hisse senetlerini primli fiyattan piyasaya çıkartmasının nedeni ise çoğunlukla onların 
piyasa değerinin itibari değerinden daha yüksek olmasıdır; tipik olarak ikinci söylenen (itibari değer) hissenin minimum değerini belirler.

Bununla birlikte hisse senedini priminin gerçek işlevi, hisselerin satış fiyatlarının gerçek piyasa değerleri ile tutarlı olmasını temin etmektir. Bu yeni hissedarların yüksek hisse değerleri üzerinden oluşmamış kazanımlar elde etmelerini engeller zira bunlar mevcut hissedarların çabaları sonucunda ortaya çıkmışır. Nitekim hisse priminin bir sebebi de yeni ve eski hissedarlar arasındaki pozisyonu dengelemektir. Bu tutum azınlık haklarının korunmasına dönüktür(Corsetti \& Meo,2012:1).

Alman Ticaret Hukukunda yargı kararlarında en üst derce mahkemenin, verdiği bir hükümde, ticari etiğe uygunluk esasının gereği olarak şirket hisselerinde çoğunluğa sahip ortakların ellerinde bulundurdukları gücünün önüne geçilerek böylece azınlığın korunabileceğini vurgulayan bir görüş bildirmektedir. (RGZ 107, 72). Alman Yüksek Mahkemesinin bir görüşüne göre; çoğunluk hisselerinin bu gücünün sınırsız görülerek ve kötü niyetli olarak şirket zararına kullanılmamalı bunun yanında sübjektif iyi niyetli olarak kullanılmasının görmezden gelinmesinin ahlaka aykırılık olduğu yönündedir(Cenkci, 2016:323).

İngiliz ve Galler Ticaret Hukukuna göre; azınlık pay sahiplerinin haklarını ve bu hakların kullanılması için gerekli koşullara gelince, azınlık pay sahipliği hakları, şirkette sahip oldukları hisselerin / oy haklarının oranına bağlı olarak aşağıdaki gibi değişir.

- $\quad$ En az\% 5 hakkı:

○ Bir kamu şirketinin özel bir şirkete dönüştürülmesini önlemek için mahkemeye başvurur;

- Genel kurul toplantısı;

- Hissedarlara (özel şirketlerde) yazılı bir kararın alınmasını gerektirir,

- Bir kamu şirketinin yıllık genel kurulunda (AGM) bir kararın alınmasını gerektirir. En az\% 10: bir karar için bir anket oyu verme hakkı.

- \% 10'dan fazlası: kısa sürede toplantının yapılmasını önleme hakkı (özel şirketlerde).

- \% 15: sınıf haklarının bir çeşidini iptal etme talebinde bulunmak için mahkemeye başvurma hakkı,

- Bu tür hissedarların varyasyona razı olmadıklarını veya lehte oy kullanmadığı koşuluyla,

- $\quad \% 25$ 'ten fazlası: özel bir kararın geçilmesini önleme hakkı,

- Azınlık hissedarları, şirketi kontrol eden yöneticilerinin davranışlarına karşı yardım talep eden "haksız önyargı" iddiası getirebilir. Alternatif olarak, hissedarlar mağduriyet sebebiyle şirketin adil bir şekilde elden çıkarılmasını isteyebilirler.

- Azınlık hissedarları, şirketin sermaye yapısında meydana gelen değişiklikleri değiştirme veya kısıtlayabilmelerine gelince; Önceden emisyon haklarını çiğnemek için özel bir kararın gerekli olduğu yerlerde azınlık hissedarları şirketin sermaye yapısındaki değişiklikleri kısıtlama hakları yoktur. Şirketin işleri, pay sahiplerinin tamamına ya da bir kısmına haksız yere zarar verecek şekilde yürütülüyorsa, bu azınlık pay sahibinin mahkemelere başvurma genel hakkına tabidir.

- Hisse senetleri şu yollarla sınırlandırılabilir:

- Hissedarlar anlaşması.

- Azınlık pay sahiplerine şirketin sermaye yapısındaki değişiklikler konusunda veto hakkı veren özel hisse hakları (Watson, McKenzie vd, 2019).

Hollanda şirket hukukuna göre; azınlık hisselerinin durumunun zayıf olması nedeniyle bu konuya özel bir önem verilmiştir. Öncelikle azınlık haklarının iyi korunması yatırımcıyı ülkeye çeker, aksi takdirde yabancı yatırımcı yatırım yapmaktan çekinebilir, bu da sermaye bulma maliyetini artıracağından rekabetin zorlaşmasını beraberinde getirecektir. Hollanda şirketler hukukunda ister büyük hisse olsun ister küçük hisse olsun, hisse pay sahiplerinin korunması kamu düzeni kapsamında değerlendirilmiştir. Hollanda şirketler hukuku, genel kurulu bir azınlık hakkı saymamaktadır, Çünkü herkese açık bir hak olarak görülmektedir. Şayet güçlü bir çoğunluk sağlanamazsa azınlık haklarının yasal yollarla veya sözleşme hükümleri çerçevesinde korunması benimsenmiştir. Hollanda şirketler hukuku azınlık haklarını dava hakkına kadar korurken aynı zamanda Hollanda 
medeni hukuku bu hisselerin bir vakıf veya dernek çatısı altında da hakların korunmasını sağlamaktadır. Başka bir yasal koruma olarak Menkul Kıymet İşlemleri ve korunması Maliye Bakanı veya delegasyon sonrası birimlerin yapacağı yasal düzenlemeler ile de kontrol altına alınmıştır. Amsterdam Exchange tarafından oluşturulan normlar izahname sunulması gibi hisse ihraç eden şirketlerin bütün hisselere eşit muamele etmesi şeklindedir. Aynı zamanda her mali olayın yayım zorunluluğu söz konusudur. Hisseler açısından, en az \%5 hisseleri oluşturan ortakların genel kurula katılma zorunluğu vardır. Hisselerin $\% 10^{\prime}$ unu temsil eden ortakların genel kurul toplantısı yapılmasını engelleme hakları vardır. Son olarak oyların $1 / 3^{\prime}$ ünü temsil eden azınlık oyları etkin olamamakla birlikte, (Genel kurul oylarının yarısından fazlasını temsil eden 2/3'lük bir çoğunluk tarafından alınan bir karar daha güçlü olmaktadır.) genel kurul oylarının 2/3'ünden fazlasına sahip olunduğunda, 2/3'ü temsil eden oyların gücü bloke etmeleri mümkündür(Timmerman, L., \& Doorman, A. s:8).

Bir başka hukuk sistemi, İsviçre şirket hukukunda verilen bir kararda; şirket hisse sahipleri herhangi bir kısıtlamaya tabi tutulmaksızın önalım (rüçhan) hakkını kullanabilecekleri vurgusu yapılmıştır. İsviçre Federal Mahkemesinin 1992 tarihli hükmü uyarınca, işletmelerin sermaye artışına gitme esansında hissedarlara tanınan rüçhan hakkı, eşit işlem ilkesi dikkate alınarak kullanılmalıdır. Şirket genel kurulunca alınacak kararda rüçhan hakkı sadece; işletmenin meşru menfaatleri gereğince ihtiyaç duyuluyor ise iyi niyet gerekçesine dayanmak, yeni hissedar almak suretiyle finansal yapıyı güçlendirmek amaçlarının yanında yatırımcı çevresinin genişletilmesi halinde sınırlandırılabilir ifadesi yer almaktadır. TTK m. 497 de de aynı ifade yer almaktadır(Çetinyılmaz, 2017:2).

Yapılan kıyaslardan da anlaşılacağı üzere, TTK, çeşitli yabancı normlardaki gibi bazı uygulamaları daha da geliştirerek hukuk sistemindeki azınlık hisselerindeki rüçhan hakkının kullanılmasını daha objektif hale getirebilir. Bu ise yargıya taşınacak uyuşmazlık sayısının azalması sonucunu doğuracaktır.

\section{BEDELLI SERMAYE ARTIRIMI YAPILMASINDA RÜÇHAN HAKKINI KULLANAMAYAN ORTAKLARIN ÖZKAYNAK HESAPLARI BAKIMINDAN MUHTEMEL KAYIPLARININ INCELENMESINE İLŞ̧KIN UYGULAMA}

Çalışmanın uygulama kısmı nitel araştırma yöntemi ile yapılacaktır. Nitel araştırma; araştırmacıların doğal ortamda mülakat, gözlem, doküman gibi çoklu metotlarla verileri elde ettiği, toplanan verilerin bütün veri kaynaklarını kapsayan kategoriler/temalar şeklinde teşkil edilip ifade edilerek bütüncül bir bakış açısıyla sunulduğu, araştırmacıların çalışmalarına kendilerini tam olarak yansıttıkları araştırma türü olarak tanımlanabilir(Creswell, 2014:45-47). Yıldırım ve Şimşek ise (2013) örnek olay araştırmasının güncel bir olgunun kendi gerçek yaşam içeriği (çerçevesi) içinde araştırılması ile birçok delil ve kaynağın var olması durumunda faydalanılan bir metot olduğunu dile getirmiştir.

McMillan ve Shumacher bilimsel araştırmayı şu şekilde tanımlamışlardır: "Bilimsel araştırma belli bir amaca yönelik olarak sistematik veri toplama ve analiz etme sürecidir". Bu yaklaşımların gerektirimlerini niteliksel araştırma yöntemleri karşılamaktadır. Bilimsel araştırma özenli ve sistematik sorgulamayı içerir; veri tabanlıdır; bu anlamda niteliksel araştırmalar bilimseldir(Özdamar, Odabaşı vd, 1999:175-176).

Çalışmada, Kamu Aydınlatma Platformundan herkesin ulaşımına açık, aleni veriler kullanılacaktır. Araştırma kapsamına uygun olarak makale ile ilgili öncelikle, doküman incelemesi ve finansal mali tablolar için veri derlemesi yapılacaktır. Bu aşamadan sonra örnek uygulamanın güvenilirlik ve geçerliliği test edilerek yorum ve değerlendirmeler buna göre yapılacaktır. Araştırmayla ilgili olarak bağımsız denetim veya Yeminli Mali Müşavir denetimden geçmiş ve karşılaştırmalı olarak verilen bilanço ve gelir tablosu kalemlerinden faydalanacaktır.

\section{ARAŞTIRMA PROBLEMI}

Sermaye şirketlerinde bedelli sermaye artırımında rüçhan hakkını kullanamayan azınlık pay sahiplerinin öz kaynak hesaplarında var olan haklarında oluşacak muhtemel kayıpların incelenmesi araştırmanın ana problemini oluşturmaktadır. Bu ana probleme ilave olarak sermaye yedekleri bakımından azınlık pay sahiplerinin kayıpkanın neler olduğu ve kar yedekleri bakımından azınlık pay sahiplerinin kayıpkarının neler oludğu alt problemleride sözkonusudur.

Bununla birlikte veri toplama ve örneklem amacıyla, araşştırmamıza örnek teşkil eden ve SPK'ya kayıtlı hali hazırda faaliyette bulunan bir Anonim Şirketin Kamu Aydınlatma Platformundan alınan verileri kullanılacaktır. Çalışmada veri toplama aracı olarak örnek olay incelemesi, doküman incelemesi: kitap, makale internet v.b. kaynaklardan elde edilecek ve diğer elde edilen ikincil veri kaynaklarındaki veriler (Bilanço, Gelir Tablosu ve Kar Dağıtım Tablosu) kıyaslama yapılarak olay değerlendirmesi yapılacaktır.

TMS 1 Standardı gereğince; bu standardın amacı, işletmenin genel amaçlı finansal tablolarının önceki dönemin finansal tablolarıyla ve diğer işletmelerin finansal tablolarıyla karşılaştırılmasına olanak verecek biçimde sunulması için gerekli olan 
temel unsurları açıklamaktır. Bu amaca ulaşmak için standart, finansal tabloların sunuluşuyla ilgili genel kuralları, yapıyla ilgili açıklamaları ve içerikle ilgili asgari koşulları ortaya koyar. TMS 1gereğince örnek olay çalışması yapılabilmesi için finansal tablolara müracaat edilecektir.

\section{ANALIZ VE DEĞERLENDIRMELER}

X Anonim Şirketinin bağımsız denetimden geçmiş bilançosu ve gelir tablosu örnek olarak alındığında rüçhan hakkını kullanamayan işletmelerdeki ortakların durumu daha iyi anlaşılacaktır. Gizlilik esası dikkate alınarak örnek işletmenin adıunvanı ve ortakları harflerle temsil edilmiştir. X A.Ş.'nin 31.12.2015 - 31.12.2016 yıllarına ait bilançosu şöyledir;

Tablo 1: X A.Ş.'nin 31.12.2015 - 31.12.2016 Yıllarına Ait Bilançosu (Aktif)

\begin{tabular}{|l|r|r|r|r|}
\hline VARLIKLAR & \multicolumn{3}{|c|}{$\mathbf{3 1 . 1 2 . 2 0 1 5}$} & $\mathbf{3 1 . 1 2 . 2 0 1 6}$ \\
\hline DÖNEN VARLIKLAR & & $\mathbf{2 9 . 1 2 5 . 8 8 6}$ & $\mathbf{2 6 . 0 2 6 . 5 7 6}$ \\
\hline Nakit ve Nakit Benzeri & 205.893 & & 210.862 & \\
\hline Finansal Yatıımlar & 1.071 & & 2.478 & \\
\hline Ticari Alacaklar & 12.815 .518 & & 11.794 .410 & \\
\hline Diğer Alacaklar & 509.662 & & 991.263 & \\
\hline Stoklar & 15.000 .929 & & 10.680 .600 & \\
\hline Peşin Ödenen Giderler & 272.168 & & 975.327 & \\
\hline Diğer Dönen Varlıklar & 320.645 & & 1.372 .006 & \\
\hline DURAN VARLIKLAR & & $\mathbf{6 . 6 6 2 . 1 5 3}$ & & $\mathbf{8 . 1 0 3 . 9 9 1}$ \\
\hline Maddi Duran Varlıklar & 4.960 .546 & & 7.031 .334 & \\
\hline Maddi Olmayan Duran Varlıklar & 190.460 & & 155.860 & \\
\hline Peşin Ödenmiş Giderler & 1.376 .853 & & 831.649 & \\
\hline Ertelenmiş Vergi Varlığı & 134.294 & & & \\
\hline AKTiF TOPLAM & & $\mathbf{3 5 . 7 8 8 . 0 3 9}$ & & $\mathbf{3 4 . 1 3 0 . 5 6 7}$ \\
\hline
\end{tabular}

Tablo 1: X A.Ş.'nin 31.12.2015 - 31.12.2016 Yıllarına Ait Bilançosu (Pasif)

\begin{tabular}{|c|c|c|c|c|}
\hline KAYNAKLAR & 31.12 & & 31.12 & \\
\hline KISA VADELI BORÇLAR & & 19.783.496 & & 15.489 .457 \\
\hline Finansal Borçlar & 12.448 .570 & & 9.689 .711 & \\
\hline Ticari Borçlar & 5.267 .709 & & 2.750 .683 & \\
\hline $\begin{array}{l}\text { Çalışanlara Sağlanan Faydalar Kapsamından } \\
\text { Borçlar }\end{array}$ & 140.396 & & 172.635 & \\
\hline Diğer Borçlar & 1.681 .919 & & 2.122 .299 & \\
\hline Ertelenmiş Gelirler & - & & 551.390 & \\
\hline Dönem Karı Vergi Yükümlülüğü & 15.105 & & 17.028 & \\
\hline Diğer Kısa Vadeli Yükümlülük & 229.796 & & 185.711 & \\
\hline UZUN VADELI BORÇLAR & & 5.265 .617 & & 6.891 .488 \\
\hline Finansal Borçlar & 4.139 .227 & & 5.761 .331 & \\
\hline Uzun Vadeli Karşılıklar & 1.126 .390 & & 1.130 .157 & \\
\hline ÖZ KAYNAKLAR & & 10.738 .926 & & 11.749 .622 \\
\hline Ödenmiş Sermaye & 270.000 & & 270.000 & \\
\hline Sermaye Düzeltme Farkı & 1.061 .623 & & 1.061 .623 & \\
\hline Paylara İlişkin Primler(İskontolar) & 1.231 .750 & & 1.231 .750 & \\
\hline Kardan Ayrılan Kısıtlanmış Yedekler & 1.766 .252 & & 1.783 .095 & \\
\hline Geçmiş Yıllar Karları & 5.852 .034 & & 6.210 .526 & \\
\hline Net Dönem Karı & 557.267 & & 1.192 .628 & \\
\hline PASIF TOPLAM & & 35.788 .039 & & 34.130 .567 \\
\hline
\end{tabular}


Tablo 2: X A.Ş.'nin 31.12.2015 - 31.12.2016 Yıllarına Ait Gelir Tablosu

\begin{tabular}{|c|c|c|c|c|}
\hline SÜRDÜRÜLEN FAALIYETLER & \multicolumn{2}{|c|}{$01.01 .2015 / 31.12 .2015$} & \multicolumn{2}{|c|}{$01.01 .2016 / 31.12 .2016$} \\
\hline HASILAT & 47.458 .241 & & 47.179 .245 & \\
\hline SATIŞLARIN MALIYETI & $(40.756 .337)$ & & (39.625.389) & \\
\hline BRÜT TICARI FAAL. KAR/ZARAR & & 6.701 .904 & & 7.553 .856 \\
\hline Genel Yönetim Gideri & 2.154 .380 & & 2.602 .485 & \\
\hline Pazarlama Giderleri & 886.915 & & 833.840 & \\
\hline FAALIYET KAR/ZARAR & & (3.041.295) & & (3.436.325) \\
\hline Esas Faal. Diğer Gelirler & 237.946 & & 313.059 & \\
\hline Esas Faal. Diğer Giderler & (772.375) & & (479.604) & \\
\hline ESAS FAALIYET KAR/ZARAR & & 2.766 .180 & & 3.950 .986 \\
\hline Yatırım Faaliyet Geliri & & - & & 710 \\
\hline FINANSMAN GIDERI ÖNCESI KAR/ZARAR & & 2.766 .190 & & 3.951 .696 \\
\hline Finansman Geliri & 302.114 & & 221.900 & \\
\hline Finansman Gideri & $(2.193 .683)$ & & $(2.612,320)$ & \\
\hline SÜRDÜRÜLEN FAAL VERGI ÖNCESI K/Z & & 874,611 & & 1.511 .276 \\
\hline Dönem Vergi Gideri & $(274.791)$ & & $(269.503)$ & \\
\hline Ertelenmiş Vergi Gideri & $(42.555)$ & & (49.145) & \\
\hline DÖNEM K/Z & & 557.267 & & $1.192,628$ \\
\hline
\end{tabular}

Tablo 3: X A.Ş 31.12.2016 Tarihli Kar Dağıtım Tablosu

\begin{tabular}{|l|r|}
\hline Sermaye & $270.000,00$ \\
\hline Ödenmemiş Sermaye & $\theta$ \\
\hline Dönem Karı & $1.511 .276,00$ \\
\hline Ödenecek Vergi & $318.648,00$ \\
\hline Net dönem Karı & $1.192 .628,00$ \\
\hline Geçmiş Yıl Zararı & $\theta$ \\
\hline Dağıtılabilir Kar & $1.192 .628,00$ \\
\hline Ayrılan ı. Tertip Yedek \%20 & $820.630,00$ \\
\hline I.Tertip Yasal Yedek \%05 & $\theta$ \\
\hline Net Dağıtılabilir Dönem Karı & $1.192 .628,00$ \\
\hline Yıl İçi Bağış & $\theta$ \\
\hline Ortaklara ı. Temettü \%05 & $13.500,00$ \\
\hline Yönetim Kurulu Üyelerine Temettü & $\theta$ \\
\hline Ortaklara II.Temettü \%100 & $1.061 .215,20$ \\
\hline II.Tertip Yasal Yedek \%10 & $117.912,80$ \\
\hline Toplam Temettü Tutarı & $1.074 .715,20$ \\
\hline Stopaj Kesintisi \%15 & $161.207,28$ \\
\hline Toplam Net Temettü Tutarı & $913.507,92$ \\
\hline Toplam Hisse Adedi & 27.000 .000 \\
\hline Hisse Başına Net Temettü Tutarı & $0.033,13$ \\
\hline Dağıtılacak Karın Sermaye Oranı & 338.33626 \\
\hline
\end{tabular}

Tablo 4: X A.Ş'nin Sermayesinin Ortaklara Dağıımı

\begin{tabular}{|c|c|c|c|c|c|}
\hline Ortak & A & $\% 40$ & $270.000 \times 0.40$ & $=$ & 108.000 \\
\hline Ortak & B & $\% 25$ & $270.000 \times 0.25$ & $=$ & 67.500 \\
\hline Ortak & C & $\% 15$ & $270.000 \times 0.15$ & $=$ & 40.500 \\
\hline Ortak & D & $\% 10$ & $270.000 \times 0.10$ & $=$ & 27.000 \\
\hline Ortak & E & $\% 10$ & $270.000 \times 0.10$ & $=$ & 27.000 \\
\hline
\end{tabular}


X AŞ'nin bedelli hisse artırımına gitmesi ve genel kurulda bunun kabul edilmesi halinde, kanun gereği rüçhan haklarının kullanılmasına ve bu kullanımın Ticaret Kanunu 461'inci maddesinde belirtilen şekilde yapılması gerekmektedir. Aynı zamanda rüçhan hakkının kullanımı sonucunda her ortak sermaye payına sahip miktar veya oran nispetinde bedelli veya bedelsiz olarak alma hakkına sahip olacaktır. Anonim şirketlerde karar alma oy çokluğuyla olacağından \%51 hisseye sahip ortaklar mutlak çoğunluk olarak karar alma yetkisine sahip olacaklardır. Bu oran aynı zamanda mutlak hâkimiyeti temsil edecek ve gelecekle ilgili tüm kararların şekillenmesini sağlayacaktır. Bu aynı zamanda sermaye payının çoğunluğunu elinde bulunduran ortak veya ortakların kanuni hakkıdır. Diğer taraftan \%50'nin altında sermaye payına sahip ortakların şirketle ilgili alınacak kararlarda bir etkinliği olmayacağından bu pay sahiplerini azınlık olarak nitelendirmek mümkündür.

X A.Ş. için azınlık olarak nitelenen ortakların sermaye paylarında ve sermayeden kaynaklanan hakları bakımından nasıl bir durumla karşılaşacakları farazi olarak yapılacaktır. Örneklemde açıkça ortaya çıkmakta ve azınlık durumunda bulunan, karar almada etkin olmayan ortakların rüçhan haklarını kullanmaması veya kullanamaması durumundan hem sermaye paylarında hem de sermaye paylarına dayalı haklarında bir kayba uğradıkları gösterilmeye çalışılacaktır.

X A.Ş.'nin 2015 yılı genel kurulunda sermaye paylarının bedelli hisse satışı şeklinde bir karar aldığını ve bu kararın A ve B ortaklar tarafından sunulup desteklendiği varsayıldığında, X A.Ş.'nin sermaye payının \%65 gibi mutlak hâkimiyetle ve oy çokluğuyla kararlaştırılabileceği açıktır. Bu karar doğrultusunda Ortaklar C, D ve E sermaye paylarının \%35'te kaldığı için TTK'nın 461. Maddesine göre karara uymaktan başka alternatifleri kalmayacaktır. Alınacak kararın 2015 yılının kar payının dağıtılmamasına ve şirket sermayesinin dört kat artırılarak günün ekonomik şartlarına uygun hale getirilmesine, pay artışında ortakların öncelikle rüçhan haklarını kullanmasına yöneliktir. Şayet bu hakkı kullanmayan olursa diğer ortaklara bu payların satılmasına eğer diğer ortaklar pay almaktan vazgeçerse bu payların \%20 karla üçüncü şahıslara satılmasına \%65 oy çokluğuyla kararlaştırılmıştır şeklinde bir karar alınması Ticaret Kanunu açısından hukuka uygun bir karar olacaktır. Bu kararın uygulandığı ve 2016 yılı için ortaya çıkacak durumun tespiti için bu farazi durumun sürdüğü varsayıldığında aşağıdaki durum ortaya çıkacaktır.

\section{1. Sermaye Dağılımı Açısından}

Sermaye artırımı sonucunda yeni oluşacak sermaye 1.080.000 TL olacaktır. Bütün ortaklar rüçhan haklarını kullanacak olursa oluşacak yeni sermaye dağılımı;

Tablo 5: X AŞ'nin Yeni Duruma Göre Oluşan Sermaye Dağılımı

\begin{tabular}{|c|c|c|c|c|}
\hline Ortak & $\mathrm{A}$ & $1.080 .000 \times 0.40$ & $=$ & 432.000 \\
\hline Ortak & $\mathrm{B}$ & $1.080 .000 \times 0.25$ & $=$ & 270.000 \\
\hline Ortak & $\mathrm{C}$ & $1.080 .000 \times 0.15$ & $=$ & 162.000 \\
\hline Ortak & $\mathrm{D}$ & $1.080 .000 \times 0.10$ & $=$ & 108.000 \\
\hline Ortak & $\mathrm{E}$ & $1.080 .000 \times 0.10$ & $=$ & 108.000 \\
\hline
\end{tabular}

Bu durumda ortakların sermaye paylarında bir değişiklik olmayacaktır ve her bir ortağın sermayeden kaynaklanan haklarında bir kaybı söz konusu olmayacaktır. Ortakların her birinin yeni çıkarılan hisseye ödeyecekleri tutar ise şu şekilde olacaktır;

Tablo 6: X AŞ’nin Sermaye Artırımı Sonucu Yeniden Alınması Gereken Hisse Tutarları

\begin{tabular}{|c|c|c|c|r|}
\hline Ortak & A & $432.000-108.000$ & $=$ & 324.000 \\
\hline Ortak & B & $270.000-67.500$ & $=$ & 202.500 \\
\hline Ortak & C & $162.000-40.500$ & $=$ & 121.500 \\
\hline Ortak & D & $108.000-27.000$ & $=$ & 81.000 \\
\hline Ortak & E & $108.000-27.000$ & $=$ & 81.000 \\
\hline
\end{tabular}

Sermaye artırımı ortaklar için toplam 810.000 TL olup bu 810.000 .000 yeni hisse anlamına gelmektedir. Toplam hisse adedi ise 1.080.000.000 adet olacaktır.

X AŞ'de ortaklardan biri veya daha fazlasının sermaye artırımına katılmaması durumunda bu tutarın kararda belirtildiği gibi diğer ortaklar tarafından alınması halinde durum sermaye payı olarak değişeceği gibi sermaye payıyla bağlantılı haklarda da değişiklik olacak ve rüçhan hakkını kullanamayan ortak aleyhine gelişecektir. Ortak C'nin sermaye artıımından dolayı hisse almak için rüçhan hakkını kullanmadığı varsayılırsa bu durumda alınan karar doğrultusunda bu payı diğer ortaklar alabileceği 
gibi üçüncü bir şahıs da bu payı alabilecektir. Ortak C'nin almadığı payların ortak A tarafından alınması durumunda sermaye payı aşağıdaki gibi olacaktır;

Tablo 7: X AŞ’nin Sermaye Artırımı Sonucu Ortak C'nin Almadığı Payların Ortak A Tarafından Alınması Durumunda Sermaye Payı Dağılımı

\begin{tabular}{|l|l|l|r|}
\hline Ortak & A & $=$ & 553.500 \\
\hline Ortak & B & $=$ & 270.000 \\
\hline Ortak & C & $=$ & 40.500 \\
\hline Ortak & D & $=$ & 108.000 \\
\hline Ortak & E & $=$ & 108.000 \\
\hline
\end{tabular}

Tablo 8: Ortakların Sermaye Üzerindeki Yeni Pay Oranları Dağılımı

\begin{tabular}{|c|c|c|r|l|r|}
\hline Ortak & A & Sermaye oranı & $553.500: 1.080 .000$ & $=$ & $51,25 \%$ \\
\hline Ortak & B & Sermaye oranı & $270.000: 1.080 .000$ & $=$ & $25,00 \%$ \\
\hline Ortak & C & Sermaye oranı & $40.500: 1.080 .000$ & $=$ & $3,75 \%$ \\
\hline Ortak & D & Sermaye oranı & $108.000: 1.080 .000$ & $=10,00 \%$ \\
\hline Ortak & E & Sermaye oranı & $108.000: 1.080 .000$ & $=10,00 \%$ \\
\hline
\end{tabular}

Bu dağılım ile Ort. A çoğunluğu elde etmiş ve mutlak hâkimiyete sahip olarak tüm kararlarda tek kişi olarak karar alma gücüne sahip olmuştur. Diğer dört ortak azınlık durumuna düşmüştür. Bu durum önceki durumla karşılaştırıldığında Ort. A karar alabilmek için diğer ortaklardan en az birinin onayına ihtiyaç duyarken yeni pay dağılımında ise karar almada hiçbir ortağın onayına gerek duymamaktadır. Ortak C'nin rüçhan hakkını kullanmaması kendisinin sermaye payında bir düşüşe sebebiyet verirken aynı zamanda diğer ortaklarında azınlık durumuna düşmesine ve karar almada mutlak karar alıcı olarak $A^{\prime}$ nın hâkimiyetine de neden olmuştur. Ortak A'nın dışında diğer ortaklıkların bu payı alması durumunda bir nebze olsun denge sağlanmış olacaktır.

Tablo 9: Ortak B'nin Bu Payı Alması Halinde Sermaye ve Pay Dağılımı

\begin{tabular}{|l|c|r|}
\hline Ortak & A & 432.000 \\
\hline Ortak & B & 391.500 \\
\hline Ortak & C & 40.500 \\
\hline Ortak & D & 108.000 \\
\hline Ortak & E & 108.000 \\
\hline
\end{tabular}

Tablo 10: Ortakların Sermaye Pay Oranlarının Yeniden Dağılımı

\begin{tabular}{|c|c|c|r|c|c|}
\hline Ortak & A & Sermaye Oranı & $432.000: 1.080 .000$ & $=$ & $40,00 \%$ \\
\hline Ortak & B & Sermaye Oranı & $391.500: 1.080 .000$ & $=$ & $34,25 \%$ \\
\hline Ortak & C & Sermaye Oranı & $40.500: 1.080 .000$ & $=$ & $3,75 \%$ \\
\hline Ortak & D & Sermaye Oranı & $108.000: 1.080 .000$ & $=$ & $10,00 \%$ \\
\hline Ortak & E & Sermaye Oranı & $108.000: 1.080 .000$ & $=$ & $10,00 \%$ \\
\hline
\end{tabular}

Tablo 11: Ortak D veya E’nin Bu Payı Alması Durumunda Pay Dağılımı

\begin{tabular}{|c|c|c|}
\hline Ortak & A & 432.000 \\
\hline Ortak & B & 270.000 \\
\hline Ortak & C & 40.500 \\
\hline Ortak & D & 229.500 \\
\hline Ortak & E & 108.000 \\
\hline
\end{tabular}

Tablo 12: Ortakların Sermaye Pay Oranları Yeniden Dağılımı

\begin{tabular}{|c|c|c|c|c|c|}
\hline Ortak & A & Sermaye Oranı & $432.000: 1.080 .000$ & $=$ & $40,00 \%$ \\
\hline Ortak & B & Sermaye Oranı & $270.000: 1.080 .000$ & $=$ & $25,00 \%$ \\
\hline
\end{tabular}




\begin{tabular}{|c|c|c|r|c|c|}
\hline Ortak & C & Sermaye Oranı & $40.500: 1.080 .000$ & $=$ & $3,75 \%$ \\
\hline Ortak & D & Sermaye Oranı & $229.500: 1.080 .000$ & $=$ & $21.25 \%$ \\
\hline Ortak & E & Sermaye Oranı & $108.000: 1.080 .000$ & $=$ & $10,00 \%$ \\
\hline
\end{tabular}

Şayet bu oranı ortaklar almayıp şirket dışında üçüncü şahıs olan F almış olsaydı, karara göre durum daha farklı olacaktır. Hissenin üçüncü şahsa satılması durumunda \% 20 ihraç pirimi ortaya çıkacak ve bu tutar 520 Hisse Senedi İhraç Primleri hesabına alınacak ve sermaye yedeği olarak hesapta kalacaktır. Bu durumda hissenin F'ye satılması sermaye payında ortaklardan birinin almasından farklı olmayacak ancak sermaye pay dağıımı etkinlik bakımımdan değişecektir.

Tablo 13: Sermaye Artııımının 3. Bir Şahıs Tarafından Alınması Durumunda Pay Dağııımı

\begin{tabular}{|c|c|c|r|}
\hline Ortak & A & Sermaye Payı & 432,000 \\
Ortak & B & Sermaye Payı & 270.000 \\
\hline Ortak & C & Sermaye Payı & 40.500 \\
\hline Ortak & D & Sermaye Payı & 108.000 \\
\hline Ortak & E & Sermaye Payı & 108.000 \\
\hline Ortak & F & Sermaye Payı & 121.500 \\
\hline
\end{tabular}

Tablo 14: Ortaklık Sermaye Pay Oranlarının Yeni Duruma Göre Dağılımı

\begin{tabular}{|c|c|c|c|c|c|}
\hline Ortak & A & Sermaye Oranı & $432.000: 1.080 .000$ & $=$ & $40,00 \%$ \\
\hline Ortak & B & Sermaye Oranı & $270.000: 1.080 .000$ & $=$ & $25,00 \%$ \\
\hline Ortak & C & Sermaye Oranı & $40.500: 1.080 .000$ & $=$ & $3.75 \%$ \\
\hline Ortak & D & Sermaye Oranı & $108.000: 1.080 .000$ & $=$ & $10,00 \%$ \\
\hline Ortak & E & Sermaye Oranı & $108.000: 1.080 .000$ & $=$ & $10,00 \%$ \\
\hline Ortak & F & Sermaye Oranı & $121.500: 1.080 .000$ & $=$ & $11.25 \%$ \\
\hline
\end{tabular}

Bu durum göstermektedir ki sermaye pay oranları dağıldıkça karar almada daha demokratik olacak ve karar alma daha çok ortağın katılmasıyla mümkün olacaktır. Bu ise ortakların pay oranlarına göre kullanılacak oyun önemini arttıracak ve azınlık durumundaki ortakların görüşleri de önem kazanacaktır.

\subsection{Kar Payı Açısından}

Sermaye payı açısından çokta göze çarpmayan azınlık durumundaki ortakların hakları, kar payı açısından ve tasfiye hali ile yedeklerin veya fonların bedelsiz hisse karşılığında sermayeye aktarılmasında önemli farklılık ve azınlık hisseleri açısından bir haksızlık ortaya çıkmaktadır.

X A.Ş.' nin 2016 yılı toplam net temettü tutarının 913.507.92 TL olduğu görülmektedir. Bu durumda sermaye payları bakımından her ortak kendi payı oranında çıkarılmış yeni hissede rüçhan hakkını kullanacak olsaydı ortakların kar dağııımından alacakları pay sermaye artırımına gitmeden önceki durumdan farklı olmayacaktır. Kar kalemi stopaj ve diğer vergiler düşüldükten sonraki net tutar olarak hesaplanmıştır.

Tablo 15: 2016 Yılı Stopaj ve Vergiler Düşüldükten Sonra Kalan Kar Tutarı

\begin{tabular}{|l|c|l|l|l|l|l|r|}
\hline Ortak & A & Kar Payı & 913.507 .92 & $\times$ & 0,40 & $=$ & $365.403,17$ \\
\hline Ortak & B & Kar Payı & $913.507,92$ & $\times$ & 0,25 & $=$ & $228.376,98$ \\
\hline Ortak & C & Kar Payı & $913.507,92$ & $\times$ & 0,15 & $=$ & $137.026,19$ \\
\hline Ortak & D & Kar Payı & $913.507,92$ & $\times$ & 0,10 & $=$ & $91.350,79$ \\
\hline Ortak & E & Kar Payı & $913.507,92$ & $\times$ & 0,10 & $=$ & $91.350,79$ \\
\hline \multicolumn{7}{|c|}{ TOPLAM } & $913.507,92$ \\
\hline
\end{tabular}

Ortak C ' nin rüçhan hakkını kullanmadığını varsayımı ile hareket edildiğinde durum çok farklı olacaktır. Ortak A'nın kalan hisseleri aldığı birinci duruma göre kar dağılımı aşağıdaki gibi olacaktır; 
Tablo 16: Ortak A’nın Kalan Hisseleri Aldığı Birinci Duruma göre Kar Dağılımı Olacaktır;

\begin{tabular}{|c|c|c|r|c|r|c|r|}
\hline Ortak & A & Kar Payı & 913.507 .92 & $\times$ & 0,5125 & $=$ & $468.172,81$ \\
\hline Ortak & B & Kar Payı & $913.507,92$ & $\times$ & 0,25 & $=$ & $228.376,98$ \\
\hline Ortak & C & Kar Payı & $913.507,92$ & $\times$ & 0,0375 & $=$ & $34.256,55$ \\
\hline Ortak & D & Kar Payı & $913.507,92$ & $\times$ & 0,10 & $=$ & $91.350,79$ \\
\hline Ortak & E & Kar Payı & $913.507,92$ & $\times$ & 0,10 & $=$ & $91.350,79$ \\
& & & & TOPLAM & $913.507,92$ \\
\hline
\end{tabular}

Tablo 17: Ortak B'nin Hisseleri Alması Durumunda Kar Dağılımı

\begin{tabular}{|c|c|c|r|c|r|c|r|}
\hline Ortak & A & Kar Payı & 913.507 .92 & $\times$ & 0,40 & $=$ & $365.403,17$ \\
Ortak & B & Kar Payı & $913.507,92$ & $\times$ & 0,3625 & $=$ & 331.146 .62 \\
\hline Ortak & C & Kar Payı & $913.507,92$ & $\times$ & 0,0375 & $=$ & $34.256,55$ \\
\hline Ortak & D & Kar Payı & $913.507,92$ & $\times$ & 0,10 & $=$ & $91.350,79$ \\
\hline Ortak & E & Kar Payı & $913.507,92$ & $\times$ & 0,10 & $=$ & $91.350,79$ \\
\hline \multicolumn{70}{|c|}{ TOPLAM } & $913.507,92$ \\
\hline
\end{tabular}

Tablo 18: Ortak D veya Ortak E’nin Bu Hisseleri Alması Durumunda Kar Dağılım

\begin{tabular}{|c|c|l|r|c|r|r|r|}
\hline Ortak & A & Kar Payı & 913.507 .92 & $\times$ & 0,40 & $=$ & $365.403,17$ \\
\hline Ortak & B & Kar Payı & $913.507,92$ & $\times$ & 0,25 & $=$ & $228.376,98$ \\
\hline Ortak & C & Kar Payı & $913.507,92$ & $\times$ & 0,0375 & $=$ & $34.256,55$ \\
\hline Ortak & D & Kar Payı & $913.507,92$ & $\times$ & 0,2125 & $=$ & $194.120,43$ \\
\hline Ortak & E & Kar Payı & $913.507,92$ & $\times$ & 0,10 & $=$ & $91.350,79$ \\
\hline \multicolumn{7}{|c|}{ TOPLAM } & $913.507,92$ \\
\hline
\end{tabular}

Tablo 19: Ortak $C^{\prime}$ nin rüçhan hakkının kullanmamasından doğan bedelli hisselerin dışardan üçüncü kişi F'ye satılması halinde kar payı dağılımı

\begin{tabular}{|c|c|l|r|r|r|r|r|}
\hline Ortak & A & Kar Payı & 913.507 .92 & $\times$ & 0,40 & $=$ & $365.403,17$ \\
\hline Ortak & B & Kar Payı & $913.507,92$ & $\times$ & 0,25 & $=$ & $228.376,98$ \\
\hline Ortak & C & Kar Payı & $913.507,92$ & $\times$ & 0,0375 & $=$ & 34.256 .55 \\
\hline Ortak & D & Kar Payı & $913.507,92$ & $\times$ & 0,10 & $=$ & $91.350,79$ \\
Ortak & E & Kar Payı & $913.507,92$ & $\times$ & 0,10 & $=$ & $91.350,79$ \\
\hline Ortak & F & Kar Payı & 913.507 .92 & $\times$ & 0,1125 & $=$ & $102.769,64$ \\
\hline \multicolumn{70}{|c|}{ TOPLAM } & $913.507,92$ \\
\hline
\end{tabular}

Ortak C'nin arttırılan bedelli sermayeden rüçhan hakkını kullanmaması ya da kullanamamasından dolayı sermaye payı \% 15 ten \%03,75 düşmüş bundan dolayı bir sonraki yıl elde edilen ve net dağıtılabilir kardan alması gereken pay 137.026,29 iken aldığı kar payı 34.256.55 TL olmuştur. Bununla birlikte senaryonun devam ettirilip gerçek kaybın asıl X A.Ş.'nin faaliyetine son vermesi, tasfiyesi, devredilmesi ya da ortağın çıkması durumunda yaşandığı görülmektedir. X A.Ş.'nin 2016 yılı bilanço değerleri üzerinde tasfiye edildiği varsayılarak tasfiye sonucunda varlıkların borçları ve öz kaynakları birebir karşıladığı düşünülür ise öz kaynak toplamı kadar ortakların sermayeleri oranında pay verileceği hukuk kuralları gereğidir. Bu durumda, 31.12.2016 yılı bilanço değerleri dikkate alınıp tüm varlıkların paraya çevrilmesi ve tüm borçların ödenmesinden sonra öz kaynak toplamı kadar tasfiye karının oluştuğu varsayıldığında, ortaklara dağıtılacak kar ya da sermaye payı 11.749.622 TL olacaktır. Vergi göz ardı edildiğinde bu tutarın sermaye payları oranında ortaklara dağıtılması bir hukuki gerekliliktir.

Söz konusu öz kaynak toplamı bilançoda belirtildiği gibi aşağıdaki kalemlerden oluşmuştur.

Tablo 20: X A.Ş’nin Bilançodaki Öz Kaynak Toplamı

\begin{tabular}{|l|r|}
\hline Ödenmiş sermaye & 270.000 \\
\hline Sermaye Düzeltme Farkı & 1.061 .623 \\
\hline Paylara İlişkin Primler (İskontolar) & 1.231 .750 \\
\hline Kardan Ayrılan Kısıtlanmış Yedekler & 1.783 .095 \\
\hline Geçmiş Yıllar Karı & 6.210 .526 \\
\hline
\end{tabular}




\begin{tabular}{|l|r|}
\hline Net Dönem Karı & 1.192 .628 \\
\hline ÖZ KAYNAK TOPLAMI & 11.749 .622 \\
\hline
\end{tabular}

X AŞ’nin Öz Kaynak toplamının tasfiye sonu karı olarak nitelendirildiğinde sermaye artırımına gidilmeden önceki sermaye payına göre dağııım yapıldığında dağılım aşağıdaki gibi olacaktır;

Tablo 21: Önceki Sermaye Payına Göre Tasfiye Sonu Kar Dağılımı

\begin{tabular}{|c|c|c|c|c|r|} 
Ortak & A & Tasfiye Payı & $11.749 .622 \times 0.40$ & $=$ & $4.699 .848,80$ \\
\hline Ortak & B & Tasfiye Payı & $11.749 .622 \times 0.25$ & $=$ & $2.937 .405,50$ \\
\hline Ortak & C & Tasfiye Payı & $11.749 .622 \times 0.15$ & $=$ & $1.762 .443,30$ \\
\hline Ortak & D & Tasfiye Payı & $11.749 .622 \times 0.10$ & $=$ & $1.174 .962,20$ \\
\hline \multicolumn{7}{|r}{} & TOPLAM & $11.749 .622,00$ \\
\hline
\end{tabular}

Ortak C'nin rüçhan hakkını kullanmaması sonucu bu payı alan Ortak A olursa bu dağılım aşağıdaki gibi olacaktır;

Tablo 22:Rüçhan Hakkını Kullanmaması Sonucu Oluşan Payını Ortak A’nın Alması Sonucu Oluşan Tasfiye Payı Dağılımı

\begin{tabular}{|c|c|l|r|r|r|r|r|}
\hline Ortak & A & Tasfiye Payı & 11.749 .622 & $\mathrm{x}$ & 0,5125 & $=$ & $6.021 .681,28$ \\
\hline Ortak & B & Tasfiye Payı & 11.749 .622 & $\mathrm{x}$ & 0,25 & $=$ & $2.937 .405,50$ \\
\hline Ortak & C & Tasfiye Payı & 11.749 .622 & $\mathrm{x}$ & 0,375 & $=$ & $440.610,82$ \\
\hline Ortak & D & Tasfiye Payı & 11.749 .622 & $\mathrm{x}$ & 0,10 & $=$ & $1.174 .962,20$ \\
\hline Ortak & $\mathrm{E}$ & Tasfiye Payı & 11.749 .622 & $\mathrm{x}$ & 0,10 & $=$ & $1.174 .962,20$ \\
\hline \multicolumn{7}{|c|}{ TOPLAM } & $11.749 .622,00$ \\
\hline
\end{tabular}

Ortak B'nin bu payı alması durumunda dağııım aşağıdaki gibi olacaktır;

Tablo 23: Rüçhan Hakkını Kullanmaması Sonucu Oluşan Payını Ortak B’nin Alması Sonucu Oluşan Tasfiye Payı Dağılımı

\begin{tabular}{|c|c|c|r|c|r|r|r|} 
Ortak & A & Tasfiye Payı & 11.749 .622 & $\mathrm{x}$ & 0,40 & $=$ & $4.699 .848,80$ \\
\hline Ortak & B & Tasfiye Payı & 11.749 .622 & $\mathrm{x}$ & 0,3625 & $=$ & $4.259 .237,98$ \\
\hline Ortak & C & Tasfiye Payı & 11.749 .622 & $\mathrm{x}$ & 0,0375 & $=$ & $440.610,82$ \\
Ortak & D & Tasfiye Payı & 11.749 .622 & $\mathrm{x}$ & 0,10 & $=$ & $1.174 .962,20$ \\
\hline Ortak & E & Tasfiye Payı & 11.749 .622 & $\mathrm{x}$ & 0,10 & $=$ & $1.174 .962,20$ \\
\hline \multicolumn{7}{|c|}{ TOPLAM } & $11.749 .622,00$ \\
\hline
\end{tabular}

Ortak D veya Ortak E'nin bu payı alması durumundaki dağılım aşağıdaki şekilde olacaktır;

Tablo 24: Rüçhan Hakkını Kullanmaması Sonucu Oluşan Payını Ortak D’nin ve Ortak E'nin Alması Sonucu Oluşan Tasfiye Payı Dağılımı

\begin{tabular}{|c|c|c|r|c|r|r|r|}
\hline Ortak & A & Tasfiye Payı & 11.749 .622 & $\mathrm{x}$ & 0,40 & $=$ & $4.699 .848,80$ \\
\hline Ortak & B & Tasfiye Payı & 11.749 .622 & $\mathrm{x}$ & 0,25 & $=$ & $2.937 .405,50$ \\
Ortak & C & Tasfiye Payı & 11.749 .622 & $\mathrm{x}$ & 0,0375 & $=$ & $440.610,82$ \\
\hline Ortak & D & Tasfiye Payı & 11.749 .622 & $\mathrm{x}$ & 0,2125 & $=$ & $2.496 .794,68$ \\
\hline Ortak & E & Tasfiye Payı & 11.749 .622 & $\mathrm{x}$ & 0,10 & $=$ & $1.174 .962,20$ \\
\hline \multicolumn{7}{|c|}{ TOPLAM } & $11.749 .622,00$ \\
\hline
\end{tabular}

Mevcut ortakların bu payı alamaması halinde genel kurul kararında belirtildiği şekilde \%20 primli satışı durumunda ortaya çıkacak durum ve tasfiye pay dağılımı şöyle olacaktır;

Satışa sunulan pay $121.500 \mathrm{TL}$ ve $\% 11,25^{\prime}$ tir.

Satışta ortaya çıkacak prim tutarı $121.500 \times 0,20=24.300 \mathrm{TL}$

Öz kaynaklarda paylara ilişkin primlerde hisse senedi ihraç farkı olarak 24.300 TL'lik bir fon artışı sağlayacak ve öz kaynak toplam tutarı 11.749.622 $+24.300=11.773 .922$ TL olacaktır. Bu durumda sermaye artırımından dolayı alınan ortağın sermayedeki payı da dikkate alındığında tasfiye payından \%11.25 faydalanacağı söz konusu olup buna göre, tasfiye payı dağılımı aşağıdaki şekilde olacaktır; 
Tablo 25: Son Duruma Göre Tasfiye Payı Dağııımı

\begin{tabular}{|c|c|c|r|c|r|r|r|}
\hline Ortak & A & Tasfiye Payı & 11.773 .922 & $\mathrm{x}$ & 0,40 & $=$ & $4.709 .568,80$ \\
\hline Ortak & B & Tasfiye Payı & 11.773 .922 & $\mathrm{x}$ & 0,25 & $=$ & $2.943 .480,50$ \\
\hline Ortak & C & Tasfiye Payı & 11.773 .922 & $\mathrm{x}$ & 0,0375 & $=$ & $441.522,08$ \\
\hline Ortak & $\mathrm{D}$ & Tasfiye Payı & 11.773 .922 & $\mathrm{x}$ & 0,10 & $=$ & $1.177 .392,20$ \\
\hline Ortak & $\mathrm{E}$ & Tasfiye Payı & 11.773 .922 & $\mathrm{x}$ & 0,10 & $=$ & $1.177 .392,20$ \\
Ortak & $\mathrm{F}$ & Tasfiye Payı & 11.773 .922 & $\mathrm{x}$ & 0,1125 & $=$ & $1.324 .566,22$ \\
\hline \multicolumn{78}{|c|}{} & \multicolumn{7}{|c|}{ TOPLAM } & $11.773 .922,00$ \\
\hline
\end{tabular}

\section{SONUÇ VE ÖNERILER}

Anonim şirketlerde rüçhan hakkının genel kurul kararına bağlanması ve bu hakkın müktesep hak sayılmamasının azınlık durumunda olan pay sahiplerinin hakkını sulandırmaya açık olduğu görülmektedir. 6102 sayılı TTK'nun 461. maddesi bu konuda hukuksal tedbirler getirmesine rağmen konu tartışmaya açıktır. Süregelen tüm tartışmaların rüçhan hakkının eski ortağın mali haklarının korunması üzerine yoğunlaştığı anlaşılmaktadır.

Esasen ilk derece mahkemeleri ve Yargıtay kararlarında bu hakkın hukuki olarak korunması üzerinde yoğunlaştığı görülmektedir. Rüçhan hakkını kök paya bağlı bir hak olarak tanımlayan Yargıtay kararları aynı zamanda bu kök paya sahip her kim ise, rüçhan hakkını kullanmak hakkının o kimseye ait olması gerektiğini vurgulamıştır. Diğer taraftan dış kaynak yoluyla sermaye artırımına gidilmesi durumunda, çıkarılacak bedelli hisseler üzerinde mevcut ortakların rüçhan hakkı bertaraf edilemez şeklinde karara bağlanmıştır (2016/1675 nolu karar). Rüçhan hakkının kullandırılmaması ya da çeşitli yollarla bu hakkın bertaraf edilmesi, aldatma, hile veya kişinin bilgisizliğinden yararlanma şeklinde gerçekleşmesi durumunda hukuka aykırı olacağı yine Yargıtay tarafından karara bağlanmıştır (2015/1142). Azınlık haklarının kullanılması için esas sermayenin \%10 (TTK'ya göre \%10, SPK'ya göre \%5) hisseye sahip ortakların genel kurulu toplantıya çağırma veya toplantı yapılacak ise isteklerinin gündeme alınmasını sağlama hakları söz konusudur. Özellikle Anonim şirketlerde oylar sermaye payıyla orantılı olduğu için sermaye payı yüksek olan çoğunluk istediği takdirde azınlık haklarını bertaraf edebilmektedir. Azınlık durumunda olan ortaklar, haklarını korumak için mahkemeye gitmektedirler. Ancak mahkeme süreci uzun sürmekte ve çoğu zaman kanunlar esas alındığı için bu hakkın ihlali tespit edilememektedir. Mahkeme kararlarını etkileyecek bilirkişi raporları maalesef şirket mahremiyetine takılmakta ve esaslı bir inceleme yapılamamaktadır.

Bu çalışmada, konu muhasebe teorisi açısından ele alınarak rüçhan hakkının kullanılmaması durumunda azınlık payları açısından ortaya çıkan sermaye yedekleri ve kar yedeklerindeki mali kayıplar incelenmiştir.

Sermaye artırımının gerçekleşmesi kapsamında bedelli veya bedelsiz hisselerin çıkarılması ile rüçhan hakkı oluşmaktadır. Sermaye ve kar yedeklerinin sermaye artırımında kullanııması ve esasen bu bedeller üzerinden yeni hisselerin çıkarılması literatürde bedelsiz hisse olarak tanımlanmaktadır. Bu hisseler işletmenin karından ayrılan ve dağıtılması gereken kar payının yasal veya sözleşmeye dayalı hükümleri gereğince dağıtılmayıp iç kaynak oluşturulmasından ibarettir. Bu da bedelsiz hisse senedi ile sermaye artırımı anlamına gelmektedir ve bu ortakların işletme üzerindeki hakkıdır.

Sermaye artırımının bedelli yapılması durumunda sermaye payının en az \%60'ının onayı ile artırılan tutar, mevcut ortaklara rüçhan hakları doğrultusunda verileceği gibi üçüncü şahıslara veya hak sahibi tarafından borsada da satılabilmektedir. Bu satışlar primli veya primsiz gerçekleşebilmektedir. Rüçhan hakkının kullanılması minimumda onbeş 15 maksimumda altmış günlük süreye tabidir. Bu süre içerisinde bedelli artıılan sermaye tutarını yatırmayan ortak bu hakkını kaybedecektir. Esasen bu sermaye artışı yapılırken yönetim kurulunun hazırlayacağı raporda ve satış şartlarının oluşmasında sermaye tutarı ile birlikte iç kaynaklarda biriken sermaye yedekleri ile kar yedeklerinin dikkate alınması gerekir. Bu aynı zamanda TTK'nun 461 maddesinde ifade edilen amir hüküm gereğince iç kaynaklar tüketilmeden dış kaynaklardan sermaye artırımına gidilmemesi gerektiği vurgulamaktadır. Bundan dolayı mevcut ortakların sermaye paylarından kaynaklanan hakları korunmuş olacaktır.

İşlemlerin hak kaybına sebebiyet vermemesi için bedelli sermaye artırımına gidilmeden önce sermaye yedekleri ile kar yedeklerinin ve dağıtılmayan karların tutarları oranında ortaklara hisse verilmesi gerekir. Bu işlem gerçekleşirse ve yeni oluşacak sermaye tutarının ortaklara sermaye paylarınca dağıtılması sağlanırsa, bu durum mali hakların kaybını bir nebze olsun önlemiş olacaktır. Bu işlemler gerçekleştikten sonra bedelli sermaye artırımına gidilmesi halinde rüçhan hakkının kullanılıp kullanılmaması veya bu sermaye artırımından kaynaklanan payın üçüncü şahıslara satılması halinde mevcut ortaklar açısından bir hak kaybı söz konusu olmayacaktır. Böyle bir durumda mutlak hâkimiyete sahip ortakların azınlık haklarını sulandırması da engellenmiş olacaktır. Çalışma kapsamında yer verilen uygulamada ortak C'nin rüçhan hakkını kullanamaması 
sermaye payında ciddi bir düşüşe sebebiyet vermiştir. Bu durum işletmenin tüm risklerine katlandığı ve öteden beri birikmiş olan sermaye ve kar yedeklerinin getirisinden ciddi bir şekilde olumsuz etkilenmektedir. Dolayısıyla ortak, kendi hakkı olan geçmişteki birikmiş kazançlardan faydalanmaması söz konusu olacaktır. Bu durum ortakların rüçhan hakkının kısıtlanması veya ortaklar tarafından kullanılamaması halinde hak kaybına uğradıklarını açıkça göstermektedir. Bu nedenledir ki rüçhan hakkı hep tartışma konusu olmuştur. Kanımızca bu tartışma devam edecektir.

Azınlık haklarının korunması konusunda ileri sürülebilecek hak kayıplarının yaşanmaması için yeni çıkarılacak hisselerin primli ve bu primlerin işletmenin piyasa değerine eşdeğer olabilecek şekilde fiyatının belirlenmesi hakkaniyete daha uygun olacaktır. Ayrıca bu şekilde bir sermaye artırımı öteden beri işletme riskine katlanmış ortakların haklarının korunmasını sağlayacak ve yeni ortağın henüz oluşmamış kazanımlar elde etmelerinin önüne geçilecektir. Azınlık haklarının korunması için, çoğunluk pay sahiplerinin özel menfaatleri uğruna gücünü sınırsız ve kasten kullanmasının önüne geçilmesi ve ortaklığın refahının bilinçli olarak göz ardı edilmesi ticari ahlaka aykırı sayılması gerekmektedir. Bu ancak azınlık durumundaki ortaklara veto hakkının verilmesi veya işletme sermayesinin arttırılmasında tüm ortakların menfaatinin bulunması ve oybirliği ilkesinin getirilmesi ile mümkündür.

Azınlık haklarının korunmasında üzerinde durulması gerekli önemli bir husus, işletmelerin her an sermaye ihtiyacı içinde olabileceğidir. Bu durum işletmenin yeni sermaye bulma yöntemlerinden biri olan hisse çıkarma yoluna gitmesiyle mümkündür. İşletmenin çıkaracağı sermaye hisselerinin piyasada değer görmesi önemli bir konudur. İşletmenin hissesinin yerli veya yabancı yatırımcılar tarafından tercih edilmesi azınlık haklarının nasıl korunduğuna bağlı olarak değişebilir. Kendi sermayesini emniyette hisseden, hakkının kaybolmayacağına inanan küçük pay sahipleri işletmeye yatırım yapacaktır. Böylece işletme sermaye maliyetlerini düşürecek ve hem işletme için hem de yatırımcı için karlı bir işlem halini alacaktır. Hakkın kullanılması oy çokluğu şeklinde eşitliğe dayalı bir sistem yerine kamu menfaati ve kamu düzeni göz önünde bulundurularak adaletli bir yaklaşımla sağlanması daha anlamlı olacaktır. Aynı zamanda azınlık durumundaki hissedarların mahkeme hakkının adil bir şekilde kullanılabileceği ve mahkemenin hakkın korunmasında adil bir karara varacağı düşüncesi ortaklık düşüncesini artıracak ve küçük sermaye sahiplerinin yatırım yapmaları teşvik edilecektir. Bu durum işletmeler, ortaklar ve ülke menfaati için daha yararlı olacaktır.

Bu çalışmanın başında da değinildiği gibi Türk Ticaret Kanunu'nun 462 maddesi3. bendinde belirtildiği gibi, işletmelerin sermayelerine aktarabilecekleri ve bilançolarında öz kaynaklar grubunda bulunan fonların sermayeye dönüştürülmesi esastır. Esasen bu fonlar sermayeye dönüştürülmeden sermaye taahhüdünde bulunularak bedelli sermaye artırımına gidilmemesi gerektiği belirtilmiştir. Aynı zamanda hem bu fonların sermayeye dönüştürülmesi hem de aynı zamanda ve aynı oranda sermayenin taahhüt edilmesi yoluyla sermaye artırılabilir. Sermaye artırımı genel kurul veya yönetim kurulu kararının ve esas sözleşmenin ilgili maddelerinin değişik şeklinin tescili ile kesinleşir. Tescil ile o an itibariyle mevcut pay sahipleri mevcut paylarının sahip oldukları sermaye oranına göre bedelsiz payları kendiliğinden iktisap ederler. Bedelsiz paylar üzerindeki hak kaldırılamaz ve sınırlandırılamaz; bu haktan vazgeçilemez.

Bir nebze de olsa müktesep hak sorununu çözmek için Türk Ticaret Kanunu 462/3 maddesi gereğince sermaye ve kar yedekleri veya geçmiş yıllar karları kullanılmadan bedelli sermaye artırımı yolu tercih edilmemelidir. Aynı zamanda azınlık hakkının korunmasında mevcut hükümlerde ileri sürülen eşitlik ilkesi adalet ilkesi ile örtüştürülmez ise, yüksek pay sahibi ve iyi niyetli olmayan aynı zamanda kasıtı davranan ortaklar tarafından azınlık haklarının sulandırılması söz konusu olabilecektir.

Yapılan araştırmalarda, rüçhan hakkı mevcut ortakların şirket üzerindeki öteden beri süregelen ve çeşitli risklere katlanarak işletmeyi mevcut duruma gelmesinde çabası olan ortakların öncelik hakkı şeklinde tanımlanmıştır. Buna göre işletmenin eski ortaklarının sermaye üzerindeki hakları rakamsal olmaktan çok şirketin şerefiyesi üzerindeki hak olarak benimsenmesi ve özellikle azınlık durumundaki ortakların sadece genel kurul kararlarıyla sınırlandırımaması gerektiği kanaati hasıl olmuştur. Ayrıca, TTK hükümlerinde rüçhan hakkının \%60 oyla bertaraf edilebileceği hükmünün azınlık haklarını hiçe saydığı düşünülmektedir. Rüçhan hakkının kullanılmasında verilen 15 günlük süre ise hakkın kullanılmasını kısıtlayıcı bir özellik olarak algılamak mümkündür. Bu durumda iyi niyet sahibi olmayan ortakların yüksek oy haklarına dayanarak azınlık hakkını akamete uğratacağı açıktır. Yukarıdaki açıklama ve kıyaslardan da anlaşıldığı gibi rekabet ortamının getirdiği globalleşen ticari anlayışta azınlık haklarının korunması ve bunun Hollanda, Almanya, İngiltere ve İsviçre hukukunda olduğu gibi korunur olması hem ülke ticaretinde hem de ortaklık düşüncesinde güçlü bir anlayış ve ilerleme getirebileceği düşünülmektedir. 


\section{KAYNAKLAR}

Borsa İstanbul, (Resmi Web Sitesi) (2018, 8 Şubat) (http://www.borsaistanbul.com/urunler-ve-piyasalar/urunler/paylar/hisse-senedicesitleri)/ adresinden erişildi.

Bozkurt, T, (2014), Şirketler Hukuku, İstanbul, (1. Baskı), Themis Yayınları.

Cenkci, E., (2016), Kayıtlı Sermaye Sisteminde Yeni Pay Alma (Rüçhan) Hakkının Sınırlandırılması Bağlamında Genel Kurul Yetkisi-Alman ve İsviçre Hukuku ile Karşılaştırmalı, TBB Dergisi,122..323

Corsetti, B., ve Meo, R., (2012), Corporate Capitalin Creases: Share Premium and Minority Interests, İtalya. (2018,2 Şubat) (https://portolano.it/news/corporate-capital-increases-share-premium-and-minority-interests)/ adresinden erişildi.

Collin, S.M.H., (2007), Dictionary of Accounting, Fourth Edition, London, A \& C Black Publishers Ltd.

Creswell, J. W., (2013), Nitel Araştırma Yöntemleri: Beş Yaklaşıma Göre Nitel Araştırma Deseni, Ankara, Siyasal Kitabevi.

Çetinyılmaz E., (2017), Anonim Şirketlerde Rüçhan Hakkı, S:2 (2018, 5 Şubat) http://www.erdem-erdem.av.tr/yayinlar/hukukpostasi/anonim-sirketlerde-ruchan-hakki/\# ednref8/adresinden erişildi.

Çiftçi Y., (2000), Türk Mevzuatında Bedelsiz Hisse Senetlerinin Niteliği, Değerlemesi ve Muhasebeleştirmesi, Mevzuat Dergisi, Yıl:3, Sayı:31, S:1 Temmuz.(2018, 5 Nisan) ( https://www.mevzuatdergisi.com/2000/07a/01.htm)/ adresinden erişildi.

Er B., Şahin Y.,E., ve Mutlu., M., (2015), Girişimciler İçin Alternatif Finansman Kaynakları, Mevcut Durum ve Öneriler, Uluslararası Ekonomi ve Yenilik Dergisi, (1),. 31-54.(2018, 9 Nisan) (http://dergipark.gov.tr/download/article-file/161808)/ adresinden erişildi.

Eriş, N., (2009), Bedelli ve Bedelsiz Sermaye Artırımlarının Yatırımcın Davranışları Üzerindeki Etkisi: IMKKB Şirketleri Üzerinde Ampirik Bir Çalışma", Ankara Üniversitesi, Sosyal Bilimler Enstitüsü,( Yüksek Lisans Tezi) Ankara, Turkey.

Gençoğlu, Ü.G, Önce, S., Ekergil, V., Köse, T., Başar, B., (2013), Genel Muhasebe II, Ankara, T.C. Anadolu Üniversitesi Yayını o: 2897, Açıköğretim Fakültesi Yayını No: 1854.

Güçlü H., (2000), Azınlık Hakları Konusunda Türk Ticaret Kanunu ve Sermaye Piyasası Mevzuatında Yer Alan Düzenlemeler ile Gelişmiş Ülke Uygulamaları" (2018,22 Mart) (www.hakanguclu.com) / adresinden erişildi.

İnal, N., (2003), Adli Tıp ve Ekonomik Terimli Hukuk Sözlüğü, Ankara, Özel basım / Sözkesen Matbaacılık.

Küçüksille, E. ve Mizrahi, R., (2015), Bedelli Sermaye artırımı Duyularının Halka Açık İşletmelerin Hisse Senedi Performanslarına Etkisi: Borsa İstanbul'da Bir Araştırma", KMÜ Sosyal ve Ekonomik Araştırmalar Dergisi, 17, (29).63-69, 2015, ISSN: 2147-7833, (2018, 13 Mart) www.kmu.edu.tr./ adresinden erişildi.

Manop, B., (2008), Anonim Ortaklıklarda Azınlık Haklarının Türk Ticaret Kanunu İle Türk Ticaret Kanun Tasarısının Getirdiği Yenilikler Işığında Değerlendirilmesi, Isparta, Süleyman Demirel Üniversitesi Sosyal Bilimler Enstitüsü, İşletme Anabilim Dalı, Ticaret Hukuku Bilim Dalı, Tez Danışmanı: Yrd. Doç. Dr. M. Fahrettin ÖNDER, Yayınlamış Tez.

Okka, O., (2015), “ Analitik Finansal Yönetim Teori ve Problemler”, Ankara, Nobel Yayınları.

Özdamar K., Odabaşı Y., Hoşcan, Y., Kırcali-iftar G., Özmen A., ve Uzuner Y., (1999), Sosyal Bilimlerde Araştırma Yöntemleri, T.C. Anadolu Üniversitesi Yayınları No: 1081,Açıköğretim Fakültesi Yayınları No: 601, 1999, Eskişehir.

Özsungur Fahri, (2014), Rüçhan Hakkının Kullanılmaması ve Sermaye Artırımında Pay Taahhütlerinin Kısmen Yerine Getirilme Sorunu, Ankara, Hacettepe HFD.4 (2). 145-146.

Parasız, İ., (2007), Modern Ansiklopedik Ekonomi Sözlüğü, Bursa, Ezgi Kitabevi.

Sermaye Piyasası Kanunu, Madde:18, Kanun No: 6362, Yayım Tarihi:30.12.2012. Ankara.

Sert., Canpolat. S., (2008), Anonim Ortaklıklarda Azınlık Haklarının İncelenmesi”, TBB Dergisi,Sayı:74. (2019, 23 Aralık) (http://tbbdergisi.barobirlik.org.tr/mwginternal/de5fs23hu73ds/progress?id=Hzm6c17Cy6eRGMEXeuGCZUgNXlaFt-7ozRi36CaRnZ0, / adresinden erişildi.

Tekdüzen Hesap Planı, 5. Öz Kaynaklar Hesabı.

Timmerman, L., Doorman, A., (t.y), Rights Of Minority Shareholders In The Netherland,

2019, 12 Aralık) (www. ejcl.org>art 64-12)/ adresinden erişildi.

Türkiye Muhasebe Standardı 1 (TMS1), "Finansal Tabloların Sunuluşu ” (2018, 7 Şubat) http://kgk.gov.tr,/ adresinden erişildi.

Türk Ticaret Kanunu, Madde: 456-462, Kanun No: 6102, Yayım Tarihi:14.02.2011, Ankara. 
Watson, N., Beliz, M. ve LLP, T., S., (2019), Shareholders' Right in Pravite And Public Compenies in The UK (England And Vales):Ovirview, Law Stated as at 01-Jul-2019 (2018, 2 Şubat)

https://uk.practicallaw.thomsonreuters.com/Document/Ifb9190ad094211e598db8b09b4f043e0/View/FullText.html?originationContext=d ocHeader\&contextData=(sc.Default)\&transitionType=Document\&needTolnjectTerms=False\&docSource=a2906a3c23bb409687767d4f5f71

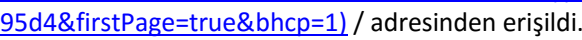

Yıldırım, A., ve Şimşek, H. ( 2013 ) . Sosyal Bilimlerde Nitel Araştırma Yöntemleri, Ankara, Seçkin Yayıncılık. 